\title{
Long-term volatility measurements of submicron atmospheric aerosol in Hyytiälä, Finland
}

\author{
S. A. K. Häkkinen ${ }^{1}$, M. Äijälä ${ }^{1}$, K. Lehtipalo ${ }^{1}$, H. Junninen ${ }^{1}$, J. Backman ${ }^{1}$, A. Virkkula ${ }^{1,2}$, T. Nieminen ${ }^{1}$, \\ M. Vestenius ${ }^{2}$, H. Hakola ${ }^{2}$, M. Ehn ${ }^{3}$, D. R. Worsnop ${ }^{1,4}$, M. Kulmala ${ }^{1}$, T. Petäjää ${ }^{1}$, and I. Riipinen ${ }^{1,5}$ \\ ${ }^{1}$ Department of Physics, University of Helsinki, P.O. Box 64, 00014 Helsinki, Finland \\ ${ }^{2}$ Finnish Meteorological Institute, Erik Palménin aukio 1, 00560 Helsinki, Finland \\ ${ }^{3}$ Institute for Energy and Climate Research (IEK-8), Forschungszentrum Jülich, 52425 Jülich, Germany \\ ${ }^{4}$ Aerodyne Research, Inc., Billerica, Massachusetts, USA \\ ${ }^{5}$ Department of Applied Environmental Science and Bert Bolin Centre for Climate Research, Stockholm University, \\ 10691 Stockholm, Sweden
}

Correspondence to: S. A. K. Häkkinen (silja.hakkinen@helsinki.fi)

Received: 18 April 2012 - Published in Atmos. Chem. Phys. Discuss.: 2 May 2012

Revised: 5 November 2012 - Accepted: 8 November 2012 - Published: 16 November 2012

\begin{abstract}
The volatility of submicron atmospheric aerosol particles was investigated at a boreal forest site in Hyytiälä, Finland from January 2008 to May 2010. These long-term observations allowed for studying the seasonal behavior of aerosol evaporation with a special focus on compounds that remained in the aerosol phase at $280^{\circ} \mathrm{C}$. The temperatureresponse of evaporation was also studied by heating the aerosol sample step-wise to six temperatures ranging from $80^{\circ} \mathrm{C}$ to $280^{\circ} \mathrm{C}$. The mass fraction remaining after heating (MFR) was determined from the measured particle number size distributions before and after heating assuming a constant particle density $\left(1.6 \mathrm{~g} \mathrm{~cm}^{-3}\right)$. On average $19 \%$ of the total aerosol mass remained in the particulate phase at $280^{\circ} \mathrm{C}$. The particles evaporated less at low ambient temperatures during winter as compared with the warmer months. Black carbon (BC) fraction of aerosol mass correlated positively with the MFR at $280^{\circ} \mathrm{C}$, but could not explain it completely: most of the time a notable fraction of this nonvolatile residual was something other than BC. Using additional information on ambient meteorological conditions and results from an Aerodyne aerosol mass spectrometer (AMS), the chemical composition of MFR at $280^{\circ} \mathrm{C}$ and its seasonal behavior was further examined. Correlation analysis with ambient temperature and mass fractions of polycyclic aromatic hydrocarbons (PAHs) indicated that MFR at $280^{\circ} \mathrm{C}$ is probably affected by anthropogenic emissions. On the other hand, results from the AMS analysis suggested that there
\end{abstract}

may be very low-volatile organics, possibly organonitrates, in the non-volatile (at $280^{\circ} \mathrm{C}$ ) fraction of aerosol mass.

\section{Introduction}

Aerosol particles, i.e. liquid or solid airborne particles, are ubiquitous in the earth's atmosphere. These particles affect our lives by reducing visibility (Cabada et al., 2004), causing adverse health effects (Davidson et al., 2005; Nel, 2005) and affecting the climate (Lohmann and Feichter, 2005; IPCC, 2007). Aerosol particles reflect and absorb incoming solar radiation (Bohren and Huffman, 1983) and affect water circulation, precipitation and the earth's radiative balance via cloud formation (Ramanathan et al., 2001; Rosenfeld et al., 2008; Spracklen et al., 2008). Aerosol particles are either directly emitted into the atmosphere in the condensed or solid phase, for example pollen from vegetation or soot from combustion, or formed in the atmosphere from ambient vapors (Kulmala et al., 2004).

Volatility, i.e. the tendency of a molecule to evaporate from the aerosol phase, as compared with its flux to the particles, is among the most important factors determining if the molecule partitions into the aerosol phase. Atmospheric aerosols are typically complex mixtures of inorganic and organic compounds. The identities and thermodynamic properties of inorganic aerosols are relatively well-known - at least 
compared with the organic fraction of atmospheric aerosol. Ambient air contains thousands of organic compounds that have complex structures and formation mechanisms (Goldstein and Galbally, 2007). A large number of these compounds still remain unidentified. Depending on the location and season, 20-90\% of the aerosol mass consists of organics (Kanakidou et al., 2005; Zhang et al., 2007; Jimenez et al., 2009). A large fraction of the organics found in aerosol particles are semi-volatile under atmospheric conditions (Robinson et al., 2007), meaning that they can be present in both gaseous and particulate phases. In order to yield reliable estimates for the total aerosol budget and to understand how the semi-volatile compounds affect the formation and fate of atmospheric aerosols, the volatility of the aerosol constituents needs to be known. Information on the aerosol volatility also gives indirect indications of the aerosol composition.

The volatility of atmospherically relevant aerosol particles has recently been investigated extensively both in the laboratory (An et al., 2007; Faulhaber et al., 2009; Cappa and Wilson, 2011; Saleh et al., 2011) and in the field. Field measurements have been performed in various environments: in rural and urban background areas (O'Dowd et al., 2000; Wehner et al., 2005; Ehn et al., 2007; Backman et al., 2010; Lee et al., 2010) as well as in polluted cities and roadsides (Wehner et al., 2004; Huffman et al., 2009; Birmili et al., 2010; Tiitta et al., 2010). In these studies, the general principle for measuring aerosol volatility has been similar: aerosol samples have been heated in a thermodenuder and the size (diameter, volume or mass) of aerosol particles determined before and after heating. Thermodenuders (TD) come in different designs, and the detected volatility depends on the temperature, residence time and total aerosol loadings in the TD (Cappa et al., 2010; Riipinen et al., 2010; Saleh et al., 2011; Fuentes et al., 2012) - making direct quantitative comparison of different volatility measurements challenging. One of the challenging aspects of the interpretation of TD data is the fact that time that it takes for the aerosol to reach equilibrium in a TD depends on the aerosol properties (Cappa et al., 2010; Riipinen et al., 2010; Saleh et al., 2011; Fuentes et al., 2012). This means that the ambient/laboratory generated aerosol does not necessarily achieve equilibrium in the currently available TDs - depending on the aerosol residence time in the TD (An et al., 2007; Riipinen et al., 2010; Saleh et al., 2011). Commercially available thermodenuders (TOPAS GmbH by TSI Inc, MN; Dekati TD by Dekati Ltd, Tampere, Finland) and the ones developed by Burtscher et al. (2001) and Wehner et al. (2002) have residence times of a few seconds. For measurements of semi-volatile organics TDs with longer residence times have been developed recently (An et al., 2007; Huffman et al., 2008). The TD used in this study is the same as described in Ehn et al. (2007) with a maximum heating temperature of $280^{\circ} \mathrm{C}$ and a residence time around a second.

Atmospheric aerosols are typically a mixture of compounds with different volatilities. For individual compounds at a fixed residence time, the evaporation inside a thermodenuder typically happens around a specific temperature, while for complex atmospheric mixtures the temperaturedependence of the aerosol remaining after heating is smoother (e.g. Riipinen et al., 2010). A large fraction of atmospheric organics and many inorganic aerosol compounds evaporate at temperatures below $300^{\circ} \mathrm{C}$ (Turpin et al., 2000; Raatikainen et al., 2010), for example ammonium sulfate at around $200{ }^{\circ} \mathrm{C}$ and ammonium nitrate at around $60-75^{\circ} \mathrm{C}$ even with residence times less than a second (Johnson et al., 2004; Philippin et al., 2004; Villani et al., 2007). However, some compounds, such as black carbon (BC), sea salt and crustal material, are not volatilized even at $300{ }^{\circ} \mathrm{C}$.

Almost all the volatility observations of submicron aerosol particles, even of nucleated particles around 3-60 nm in diameter, to date have found a non-volatile residual in the particles that does not evaporate at temperatures around 280$300^{\circ} \mathrm{C}$ in similar setups as the one used in this study (Wehner et al., 2005; Ehn et al., 2007; Birmili et al., 2010). In this study the term "non-volatile" refers to material not evaporated at $280^{\circ} \mathrm{C}$. In polluted areas, the observed non-volatile aerosol material has been found to have a clear correlation with light-absorbing aerosol (Birmili et al., 2010). Kalberer et al. (2004) show that given enough time atmospheric organic compounds may form low-volatile polymers. Recently Smith et al. (2010) reported that aminium salt formation takes place in atmospheric nanoparticles and that these low-volatile salts contribute significantly to the growth of nanoparticles in various environments, also in boreal forests. Barsanti et al. (2009) suggested that amines may have a noticeable role in the formation of organic salts. All of the aforementioned processes may be linked to the observations of low-volatility material in the small atmospheric particles.

The evaporation properties of atmospheric submicron aerosol particles were investigated in this study by examining the mass reduction of aerosols due to evaporation at six temperatures ranging from $80^{\circ} \mathrm{C}$ to $280^{\circ} \mathrm{C}$. Measurements were performed continuously during a period of two and a half years (January 2008 to May 2010) at the boreal forest site of Hyytiälä, Finland. Compared to previous studies performed in Hyytiälä (e.g. Ehn et al., 2007; Raatikainen et al., 2010), this study is the first one focusing on long-term variation of aerosol evaporation. The volatility data was compared to $\mathrm{BC}$ measurements, meteorological data and trajectory analysis as well as to aerosol composition data from filter analysis and aerosol mass spectrometer (AMS). Our main aims were to (1) study the temperature dependence of aerosol volatility in Hyytiälä, (2) investigate the seasonality of aerosol volatility and its connection to other atmospheric variables, and (3) examine the chemical composition of the non-volatile fraction (not evaporating at $280^{\circ} \mathrm{C}$ ) of atmospheric sub-micron particles, particularly to answer the question of how large fraction of this very low-volatility material was BC vs. other compounds. 


\section{Materials and methods}

\subsection{Measurement site}

Measurements for this study were performed at a rural background measurement station SMEAR II (Station for Measuring Ecosystem-Atmosphere Relations II) located in Hyytiälä $\left(61^{\circ} 51^{\prime} \mathrm{N}, 24^{\circ} 17^{\prime} \mathrm{E}, 181 \mathrm{~m}\right.$ a.s.l.), in Southern Finland (Vesala et al., 1998; Kulmala et al., 2001; Hari and Kulmala, 2005). The SMEAR II station is surrounded by 48 year old boreal conifer forest that covers an area spanning tens of kilometers to North and North-East. The nearest large cities are Tampere (around $60 \mathrm{~km}$ to South-West, 213000 inhabitants) and Jyväskylä (around $100 \mathrm{~km}$ to NorthEast, 131000 inhabitants). Ambient meteorological conditions such as temperature, relative humidity, solar radiation, wind speed and direction as well as concentrations of several trace gases, such as carbon dioxide $\left(\mathrm{CO}_{2}\right)$, carbon monoxide $(\mathrm{CO})$, sulfur dioxide $\left(\mathrm{SO}_{2}\right)$ and nitrogen oxides $\left(\mathrm{NO}_{\mathrm{x}}\right)$, are measured continuously at the station. Also the fluxes of compounds such as water, ozone and several volatile organics are measured. In addition, measurements of aerosol properties such as aerosol particle number size distributions have been ongoing at the station continuously since 1996 (Mäkelä et al., 1997).

\subsection{Instrumentation}

\subsubsection{DMPS}

The ambient aerosol number size distribution was measured from 1 January 2008 to 24 May 2010 (see Fig. 1) with a twinDMPS (Differential Mobility Particle Sizer, Hoppel, 1978; Aalto et al., 2001) consisting of two separate DMPSs operated in parallel. The first DMPS determines the size distribution of small particles, 3-50 nm in diameter, and the other measures larger particles, $15 \mathrm{~nm}-1 \mu \mathrm{m}$ in size. Together they cover the size range of 3-1000 nm. Both DMPSs sheath flows are maintained using closed loop circulation (Jokinen and Mäkelä, 1997) and at a relative humidity below $20 \%$. Condensation particle counters (CPC, Stolzenburg and McMurry, 1991) used for particle counting are TSI-3025 and TSI-3010 (TSI Inc.), respectively. The time resolution of the combined system is $10 \mathrm{~min}$.

\subsubsection{VDMPS}

The evaporation of submicron aerosol particles was investigated using a volatility differential mobility particle sizer (VDMPS), which consists of two separate parts, a thermodenuder (TD, Ehn et al., 2007) and a DMPS. The thermodenuder heats up the sample air, after which the remaining aerosol material is directed to the DMPS system. The heating temperature can be either held constant or scanned over several temperatures. The VDMPS used in this study measured the number size distribution of heated particles of 20
$1000 \mathrm{~nm}$ in diameter. A TSI model $3010 \mathrm{CPC}$ was used for particle counting. The thermodenuder was a $50 \mathrm{~cm}$ long tube fabricated from stainless steel with outer radius of $10 \mathrm{~mm}$. The average residence time, i.e. the time the aerosol sample spends in the oven, was $1.2 \mathrm{~s}$ leading into a minimum residence time of $0.6 \mathrm{~s}$ at the centerline. The time resolution of the VDMPS was $10 \mathrm{~min}$. No absorptive material was used in the thermodenuder.

The VDMPS and DMPS systems were located in the same measurement cottage and they used the same total aerosol inlet. No $\mathrm{PM}_{1.0}$ cyclone was used in front of the VDMPS, so the VDMPS was occasionally affected by evaporated coarse mode particles $(>1 \mu \mathrm{m})$ not detected by the DMPS system. These particles were detected in VDMPS after heating to high temperatures and caused noise in the VDMPS data at the larger end of particle sizes. In order to remove this noise, the size range of $20-500 \mathrm{~nm}$ was selected for further analysis.

The VDMPS was temperature-scanning from 1 January 2008 to 27 April 2009. The TD heated the aerosol sample to six temperatures, $80^{\circ} \mathrm{C}, 120^{\circ} \mathrm{C}, 160^{\circ} \mathrm{C}, 200^{\circ} \mathrm{C}, 240^{\circ} \mathrm{C}$ and $280^{\circ} \mathrm{C}$ with a time resolution of about one hour. From July 2009 onwards the aerosol sample was heated to a constant temperature, $280^{\circ} \mathrm{C}$ (Fig. 1) to obtain a complete time series of evaporation at a single temperature. Total data coverage for the measurement period (1 January 2008 to 24 May 2010) was about $75 \%$.

The major loss processes in the heating tube are caused by thermophoresis and Brownian diffusion of small particles (Wehner et al., 2002). Due to these losses, VDMPS raw data underestimates the number concentration of submicron particles. Errors in particle number concentrations were corrected using experimentally derived particle losses presented by Ehn et al. (2007). The losses for aerosol particles above $15 \mathrm{~nm}$ in diameter were observed to be around $20 \%$ of the total particle number concentration when heated to $280^{\circ} \mathrm{C}$. The same correction fit for particle penetration through the oven was used for all the six heating temperatures. The error resulting from this has been estimated to be only a few percent (Wehner et al., 2002).

\subsubsection{Aethalometer}

An aethalometer (Hansen et al., 1984) was used to measure the mass concentration of $\mathrm{BC}$ after a $\mathrm{PM}_{2.5}$ inlet. In the data inversion it is assumed that the $\mathrm{BC}$ mass concentration and light attenuation are linearly related, and BC mass is calculated from the rate of change of light transmission through a filter at seven wavelengths. However, the presence of other light-scattering and absorbing particles, such as sulfate or brown carbon, on the filter can cause non-linearities in the relationship between the light transmission and the BC concentration (Reid et al., 1998; Bond et al., 1999). The aethalometer signal needs to be corrected for these effects (e.g. Weingartner et al., 2003; Arnott et al., 2005; Andreae and Gelencsér, 2006; Virkkula et al., 2007). The errors caused by 


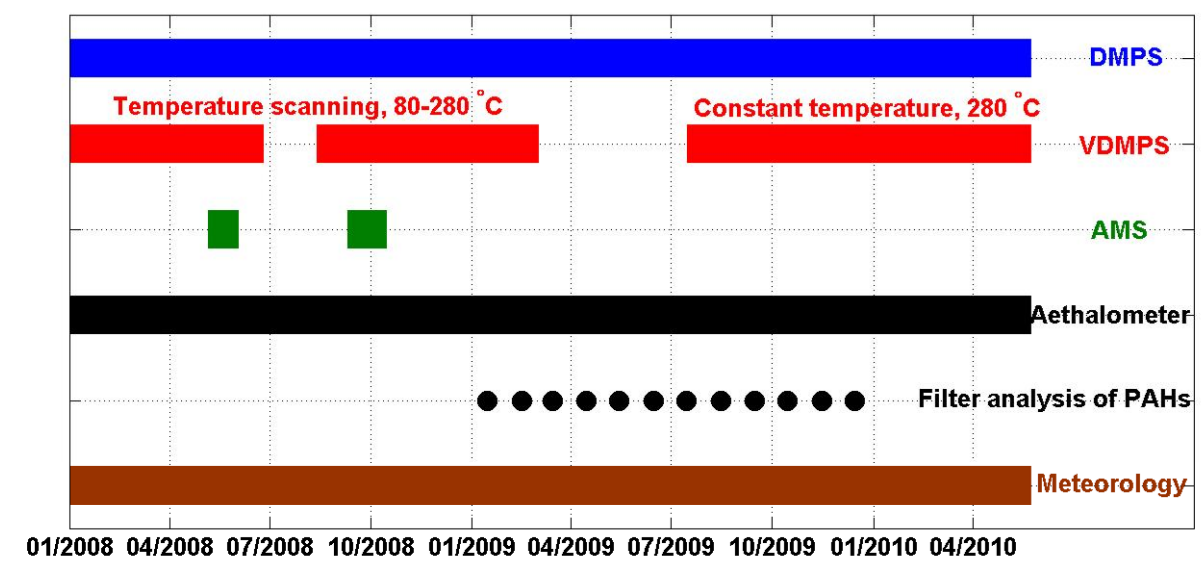

Fig. 1. Instruments used in this study and their functioning times from January 2008 to May 2010.

brown carbon can be reduced by using longer wavelengths, most preferably $880 \mathrm{~nm}$ (Weingartner et al., 2003).

Aethalometer data was corrected using the approach introduced by Weingartner et al. (2003), the resulting BC concentrations $\left(M_{\mathrm{BC}}\right)$ being defined as

$M_{\mathrm{BC}}=\frac{M_{\mathrm{BC}, \mathrm{raw}} \sigma_{\mathrm{abs}, 0}(\lambda)}{\sigma_{\mathrm{abs}}(\lambda) C(\lambda) R(\mathrm{ATN})}$,

where $M_{\mathrm{BC} \text {,raw }}$ is the $\mathrm{BC}$ concentration measured with an aethalometer (non-corrected), $\sigma_{\mathrm{abs}, 0}$ is the wavelengthdependent absorption mass cross-section used by the manufacturer of the aethalometer, $\sigma_{\mathrm{abs}}$ is the absorption mass cross-section calculated using the absorption mass crosssection of MAAP (Multiangle Absorption Photometry, Petzold and Schönlinner, 2004) as a reference point $\left(6.6 \mathrm{~m}^{2} \mathrm{~g}^{-1}\right.$ at $637 \mathrm{~nm})$, and $C$ and $R(\mathrm{ATN})$ are the calibration parameters. The calibration factor $R(\mathrm{ATN})$ can be written as

$$
R(\mathrm{ATN})=\left(\frac{1}{a\left(1-\omega_{0}\right)+1}-1\right) \frac{\ln (\mathrm{ATN})-\ln (10 \%)}{\ln (50 \%)-\ln (10 \%)}+1
$$

where $a$ is 0.85 at $660 \mathrm{~nm}$ (Weingartner et al., 2003), ATN is light attenuation through the filter and $\omega_{0}$ is a singlescattering albedo which can be derived from particle absorption and scattering measurements. Aerosol light scattering measurement data from a nephelometer (Anderson et al., 1996) was available for the period of interest. Values for absorption mass cross-sections and $C$ factors are presented in Table A1 in Appendix A. The $C$ factors were calculated by using the average $C$ value determined from Hohenpeissenberg MAAP-data by Collaud-Coen et al. (2010). Wavelength dependence of the $C$ factor was obtained from Arnott et al. (2005). Corrected BC data at $880 \mathrm{~nm}$ wavelength with a time resolution of five minutes was used in the analysis.

\subsubsection{AMS}

The Aerosol Mass Spectrometer (AMS) used in this study was an Aerodyne Compact Time-of-Flight Aerosol Mass
Spectrometer (C-ToF AMS, Aerodyne Research Inc., Billerica, US), which measures the chemical composition of submicron particles $(<600 \mathrm{~nm})$ and has a $50 \%$ detection efficiency cutoff at $600 \mathrm{~nm}$ (Jayne et al., 2000; Drewnick et al., 2005; Liu et al., 2007).

The C-ToF AMS features an aerodynamic lens for concentrating the particles into a narrow beam, a particle timeof-flight (PToF) chamber for particle size distribution measurement, thermal vaporization of the sample particles in a $600^{\circ} \mathrm{C}$ tungsten oven, $70 \mathrm{eV}$ electron impact ionization (EI) of the produced vapor, and a compact ion-time-of-fight mass spectrometer (C-ToF MS) to obtain a mass spectrum of the ions. The "hard" EI ionization method provides quantitative, yet highly fragmented ion spectra from the parent molecules.

The mass spectra of ions is interpreted, using knowledge of EI molecular fragmentation patterns, to assign the aerosol total mass loading into subgroups of different chemical composition: sulfates, organics, nitrates, ammonium and chlorides. The individual mass-per-charge signals and their relative ratios can be used to further characterize the composition of the sample aerosol. The final data is scaled with a collection efficiency factor (CE) to compensate for losses inside the AMS.

Because of the thermal vaporization method, the AMS does not quantitatively see "refractory compounds", i.e. those that are not vaporized below $600{ }^{\circ} \mathrm{C}$, such as sea salt and BC. Particulate water is also not quantitatively measured and is not included in the AMS-measured total aerosol mass.

Data used in this study was collected during two monthlong AMS-campaigns: one in late spring 2008 and one in early fall 2008 (Fig. 1).

\subsubsection{Meteorological parameters and PAH-data}

Meteorological parameters as well as mass concentrations of polycyclic aromatic hydrocarbons $(\mathrm{PAH})$ were also measured at SMEAR II. Ambient temperature and solar radiation were continuously recorded at a 72-m-tall mast at different 


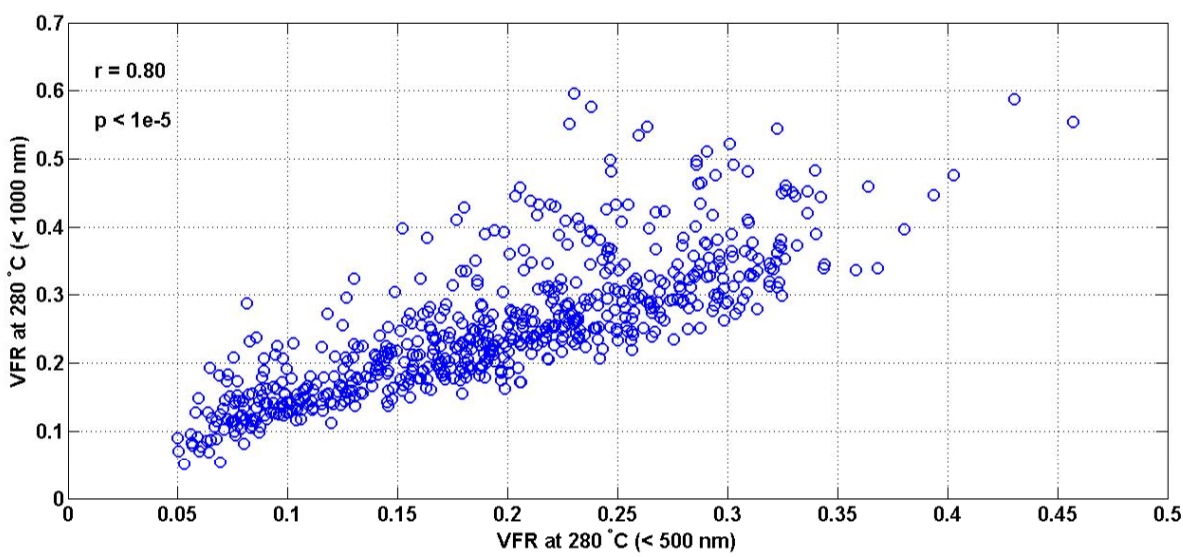

Fig. 2. Correlation between the VFR (DMPS and VDMPS $<1000 \mathrm{~nm}$ ) at $280^{\circ} \mathrm{C}$ and the VFR (DMPS and VDMPS $<500 \mathrm{~nm}$ ) at $280{ }^{\circ} \mathrm{C}$. Correlation coefficient $(r)$ and p-value describing the significance of the correlation are provided in the figure.

heights. In this study the radiation data was acquired from the height of $18 \mathrm{~m}$ whereas the ambient temperatures were measured at a lower measurement stage $(4.2 \mathrm{~m})$. The meteorological data was averaged over $30 \mathrm{~min}$. Mass concentrations of PAHs were analyzed from filter samples $\left(\mathrm{PM}_{10}\right)$ in Hyytiälä during 2009 (see Vestenius et al., 2011) (Fig. 1).

\section{Data analysis}

\subsection{Volume fraction remaining}

The evaporation of submicron particles was studied by comparing the ambient and heated particle number and volume size distributions measured by the DMPS and VDMPS. The particle volume size distribution was calculated from the number size distribution data assuming spherical particles. The volume fraction of aerosol particles remaining after heating was then defined by comparing the total volume of heated aerosol ( $\left.V_{\text {tot,VDMPS }}\right)$ to the total volume of ambient aerosol $\left(V_{\text {tot,DMPS }}\right)$. Volume fraction remaining (VFR) can be written as

$\mathrm{VFR}=\frac{V_{\mathrm{tot}, \mathrm{VDMPS}}}{V_{\mathrm{tot}, \mathrm{DMPS}}}$

As mentioned above (see Sect. 2.2.2), the size range of 20-500 nm was used for both instruments due to occasional noise in the VDMPS data at larger particle sizes. Figure 2 illustrates the correlation between VFR (DMPS and VDMPS $<1000 \mathrm{~nm}$ ) at $280^{\circ} \mathrm{C}$ and VFR (DMPS and VDMPS $<500 \mathrm{~nm})$ at $280^{\circ} \mathrm{C}$. The correlation is clear $(r=$ 0.80 ) and therefore confirms that the size range of $20-500 \mathrm{~nm}$ is representative of the total aerosol evaporation behavior. Absolute minimum estimates for the VFRs in different temperatures can be calculated selecting different size ranges for the calculations (VDMPS $<500 \mathrm{~nm}$ and DMPS $<1000 \mathrm{~nm}$ ), resulting in VFR values around $20 \%$ smaller than presented here.
We assumed a constant particle density of $1.6 \mathrm{~g} \mathrm{~cm}^{-3}$ throughout the aerosol size distribution based on the work of Kannosto et al. (2008), who report a range of $1.1-2 \mathrm{~g} \mathrm{~cm}^{-3}$ for accumulation mode particle densities in Hyytiälä. The mass fraction remaining after heating (MFR) was thus assumed to be equivalent to VFR in terms of density. The assumption of constant particle density naturally leads to uncertainties in the MFR if the particle density is in fact changing with size. This uncertainty is likely higher at the higher heating temperatures, because of the bigger change in the particle chemical composition due to evaporation. If the particles are denser after the heating than before, the real MFR values are higher values than presented in this study and vice versa. If the non-volatile residual at $280^{\circ} \mathrm{C}$ would consist of BC only (density of $1.8 \mathrm{~g} \mathrm{~cm}^{-3}$, McMeeking et al., 2010), the MFR at $280^{\circ} \mathrm{C}$ would be biased high, with around $13 \%$ as compared with the reported values. Similarly, if the particle density after the heating would be smaller than assumed, e.g. $1 \mathrm{~g} \mathrm{~cm}^{-3}$, there would be a $38 \%$ low bias in the MFR at $280^{\circ} \mathrm{C}$.

\subsection{Black carbon fraction}

The maximum fraction of $\mathrm{BC}$ in the aerosol mass $(\mathrm{BCF})$ was defined as

$\mathrm{BCF}=\frac{M_{\mathrm{BC}}}{M_{\mathrm{tot}, \mathrm{DMPS}}}$,

where $M_{\mathrm{BC}}$ is the mass concentration of $\mathrm{BC}$ from the aethalometer data (see Eq. 1) and $M_{\text {tot,DMPS }}$ is the total mass concentration of ambient $20-500 \mathrm{~nm}$ aerosol as determined from the DMPS data. To investigate the maximum contribution of BC to the MFR at $280^{\circ} \mathrm{C}$, all BC mass was removed from the observed MFR. Mass fraction remaining at $280^{\circ} \mathrm{C}$ without the effect of $\mathrm{BC}$ is then defined as follows

$\mathrm{MFR}_{\text {non-BC }}=\mathrm{MFR}-\mathrm{BCF}=\frac{M_{\mathrm{tot}, \mathrm{VDMPS}}-M_{\mathrm{BC}}}{M_{\mathrm{tot}, \mathrm{DMPS}}}$. 

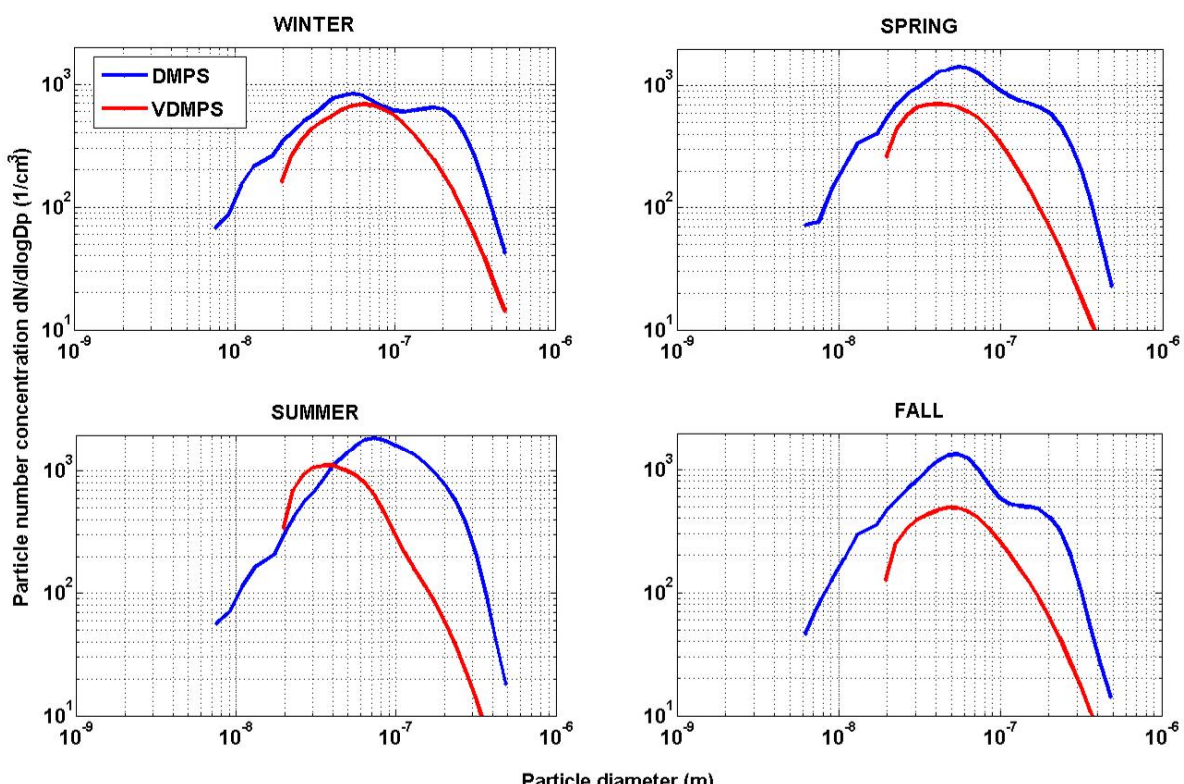

Fig. 3. Median particle number size distributions from DMPS and VDMPS at $280^{\circ} \mathrm{C}$ in different seasons.

It is now important to note that the aethalometer determined the $\mathrm{BC}$ mass concentration of $\mathrm{PM}_{2.5}$ particles. The $\mathrm{BCF}$, however, was calculated assuming that all the $\mathrm{BC}$ mass is distributed to particles smaller than $500 \mathrm{~nm}$. Hitzenberger and Tohno (2001) estimate that close to urban areas approximately $15-20 \%$ of the BC mass is in particles larger than $500 \mathrm{~nm}$. If the same is true also in Hyytiälä the error introduced to the MFR $\mathrm{non}_{\mathrm{BC}}$ at $280^{\circ} \mathrm{C}$ would increase the value of $\mathrm{MFR}_{\text {non-BC }}$ with a factor of 1.3 at maximum.

\subsection{Air mass trajectories}

To investigate the relationship between atmospheric aerosol volatility and air mass properties, the air mass origin was determined with trajectory analysis. Back trajectories of air masses arriving at Hyytiälä were modeled with HYSPLIT (HYbrid Single-Particle Lagrangian Integrated Trajectory model, Draxler and Hess, 1997), which runs via internet (Draxler and Rolph, 2011). We used hourly air mass trajectories at a $100 \mathrm{~m}$ arrival height above ground level. The trajectories were calculated $96 \mathrm{~h}$ backwards in time. In addition to the trajectories, HYSPLIT estimates the height of the mixing (boundary) layer. The average direction of the arriving air mass was determined using the trajectories that were below twofold the mixing layer height.

\section{Results and discussion}

\subsection{Ambient and non-volatile number and volume size distributions}

Figure 3 shows the median ambient and heated $\left(280^{\circ} \mathrm{C}\right)$ number size distributions for winter (December-February), spring (March-May), summer (June-August) and fall (September-November). The median ambient number size distributions were bi- or trimodal with Aitken and accumulation modes. The highest number concentrations were observed in the Aitken mode, and during summer and spring months the total particle number concentration was the highest - in agreement with previous observations (Dal Maso et al., 2005). Also nucleation mode (3-25 nm) particles are frequently observed in Hyytiälä. This mode cannot be clearly observed in Fig. 3 because of the averaging, as it has a distinct diurnal pattern. However, when examining aerosol number size distributions for days and nights separately, the nucleation mode was visible in day time number size distributions, especially during spring and fall months.

The median heated $\left(280^{\circ} \mathrm{C}\right)$ number size distributions were monomodal (Fig. 3). In general, the particle modes moved towards smaller sizes when heated, and the bimodal structure disappeared. Aerosol total number concentration after heating was noticeably lower than in the ambient air. There are at least two possible reasons for this, after the temperature-dependent losses are accounted for. First, a large fraction of the smallest aerosols can evaporate below the detection limit of the VDMPS system $(20 \mathrm{~nm})$. Second, if the aerosol is an external mixture of more and less volatile components, some particles can evaporate completely while 


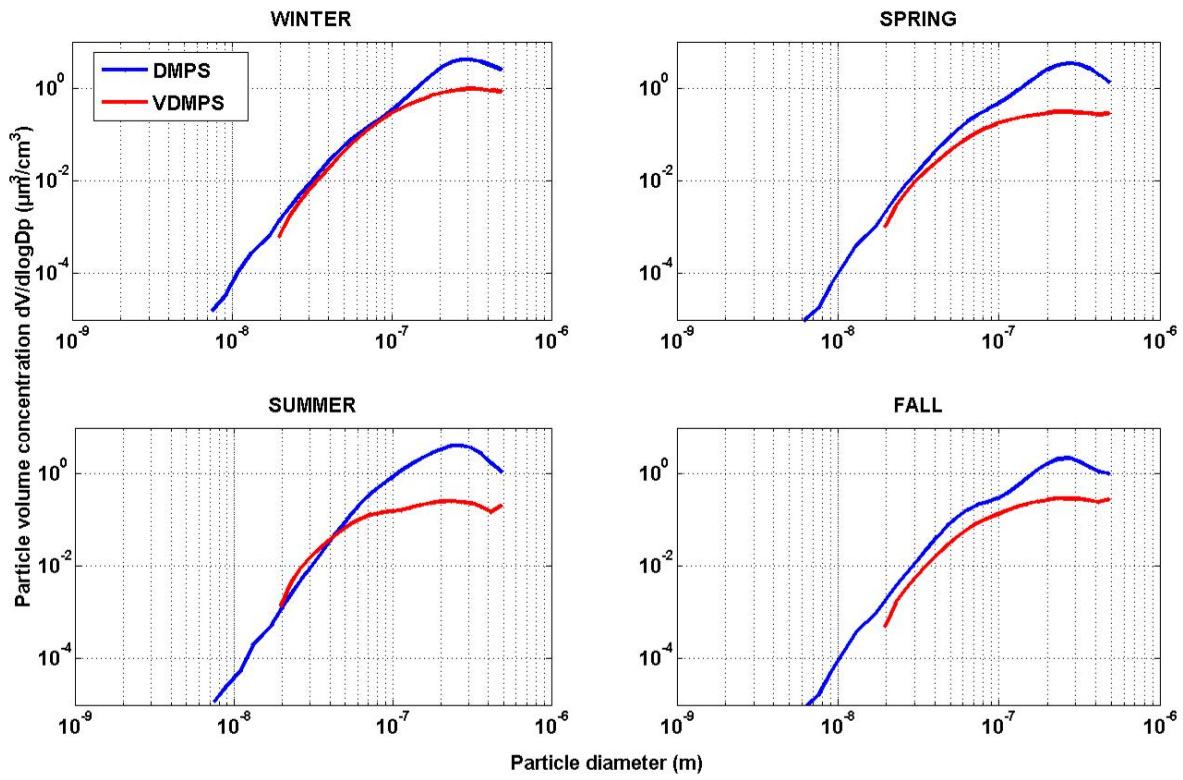

Fig. 4. Seasonal median volume size distributions from DMPS and VDMPS at $280^{\circ} \mathrm{C}$.

others remain close to their original size. We expect the former effect to be more important, in accordance with earlier findings where all nucleation mode particles were found to contain material that did not evaporate at temperatures of $280{ }^{\circ} \mathrm{C}$ (Ehn et al., 2007).

Figure 4 illustrates the median volume size distributions of particles in ambient conditions and after heating to $280^{\circ} \mathrm{C}$ during different seasons. While the ambient and heated number and volume size distributions for the winter, spring and fall look relatively similar, the corresponding distributions for summer differ from the other seasons. During the summer the distinction between the ambient Aitken and accumulation modes is less clear and the average diameter of the heated aerosol smaller than during the other seasons.

\subsection{Temperature-dependence of MFR}

Figure 5 shows the time series of the MFR at different TD temperatures. The aerosol particles were more volatile during summer, whereas the highest values of the MFR occurred during winter months (Table 1). On average $19 \%$ of the aerosol mass was left after heating the aerosol to $280^{\circ} \mathrm{C}$. In general the temporal variation of the MFR values was relatively similar, independent on the TD temperature (see Fig. 5). During the spring (especially in April/May 2008 and in March 2009), however, the MFRs below $200^{\circ} \mathrm{C}$ seemed to show an increasing trend while the MFRs at higher temperatures were decreasing. This indicates an increase in the relative fraction of aerosol components that volatilize around $200^{\circ} \mathrm{C}$ during the spring, as compared with the other months. These observations are in line with the results reported by Raatikainen et al. (2010), who studied the connection between aerosol composition and volatility during spring 2005
Table 1. Median total particle volume concentrations measured by the DMPS and VDMPS in different seasons as well as the VFR (MFR) of $20-500 \mathrm{~nm}$ particles at $280^{\circ} \mathrm{C}$.

\begin{tabular}{llrl}
\hline Season & Instrument & $\begin{array}{r}\text { Total particle volume } \\
\text { concentration }\left(\mu \mathrm{m}^{3} \mathrm{~cm}^{-3}\right)\end{array}$ & VFR \\
\hline \multirow{2}{*}{ Winter } & DMPS & 1.72 & 0.25 \\
& VDMPS & 0.38 & \\
\hline \multirow{2}{*}{ Spring } & DMPS & 1.75 & 0.17 \\
& VDMPS & 0.25 & \\
\hline \multirow{2}{*}{ Summer } & DMPS & 1.99 & 0.09 \\
& VDMPS & 0.18 & \\
\hline \multirow{2}{*}{ Fall } & DMPS & 1.00 & 0.20 \\
& VDMPS & 0.18 & \\
\hline
\end{tabular}

in Hyytiälä. They noted an anticorrelation between the MFR values between $50-150^{\circ} \mathrm{C}$ and $150-280^{\circ} \mathrm{C}$, and concluded that the material volatilizing around $150^{\circ} \mathrm{C}$ was mainly organic, while the mass remaining at the higher temperatures consisted of a mixture of organic and inorganic compounds. The MFR at $280^{\circ} \mathrm{C}$ was generally slightly higher at night (0.21) as compared to daytime values $(0.19)$.

Figure 6 shows the temperature dependence of the MFR of this study and a selection of other relevant studies. Our results are in a qualitative agreement with the earlier research. However, it should be noted that residence times and aerosol type varied from study to study. These parameters affect strongly the evaporation of aerosol particles. Ehn et al. (2007) and Wehner et al. (2005) investigated the volatility of nucleation mode particles in remote background sites 


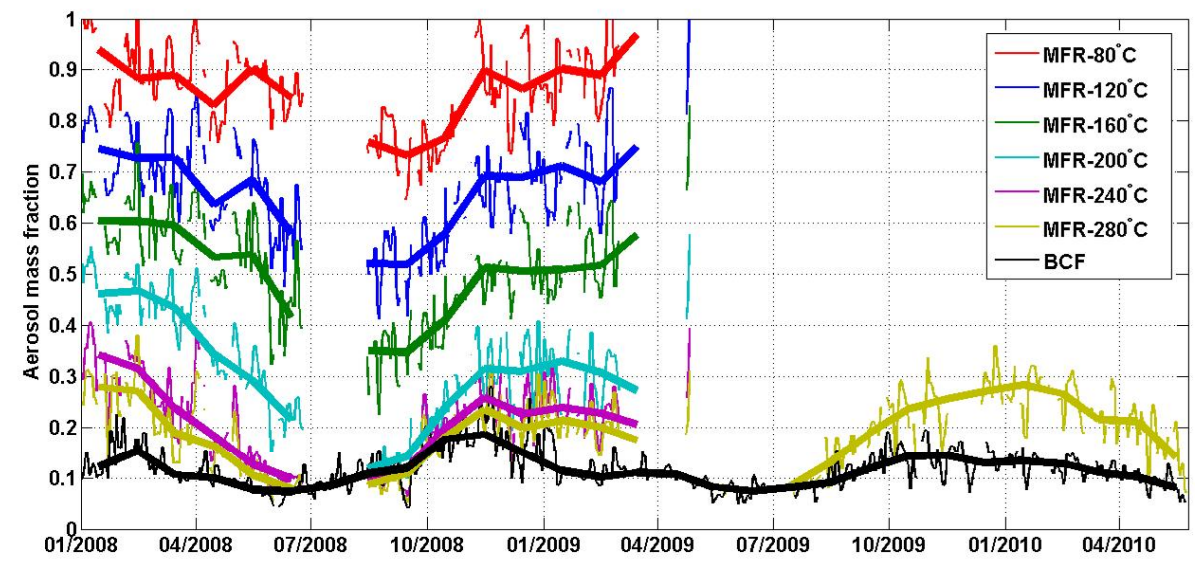

Fig. 5. Aerosol mass fraction remaining (MFR) after heating to six temperatures from $80^{\circ} \mathrm{C}$ to $280^{\circ} \mathrm{C}$ is presented (colored lines). The black line describes the maximum mass fraction of $\mathrm{BC}(\mathrm{BCF})$ in aerosol particles. Thicker lines show the monthly pattern of the parameters presented.

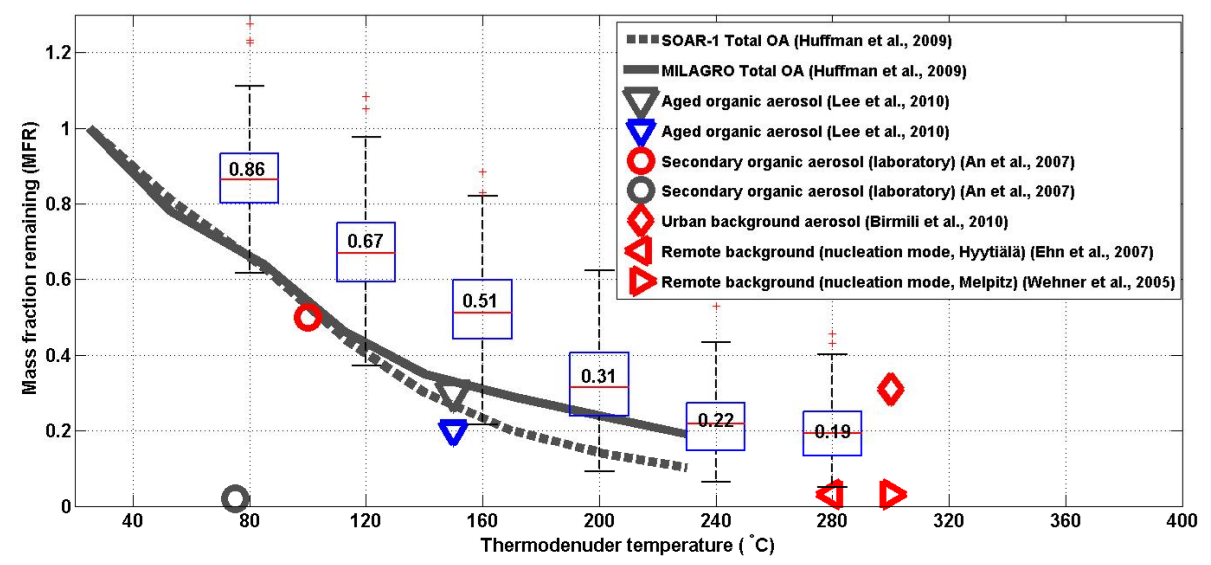

Fig. 6. Comparison of thermograms between this study (the boxplot) and previous volatility studies. Coloring describes the residence times used (red: <2 s, grey: 10-16 s, blue: > 100 s). SOAR-1 and MILAGRO campaign results are adapted from Huffman et al. (2009). Lee et al. (2010) investigated the volatility of aged organic aerosol during FAME-2008 campaign in Finokalia and volatility measurements of urban background aerosol were performed by Birmili et al. (2010) in Germany. Ehn et al. (2007) and Wehner et al. (2005) measured the volatility of nucleation mode particles in Hyytiälä and in Melpitz, respectively. Measurement results of laboratory generated secondary organic aerosol from An et al. (2007) are also presented.

by examining the change in aerosol mean diameter when heated. Other studies, including our study, determined the volume/mass decrease of particles.

In general the aerosol volatility measured in this study seems to fall close to the lower end of the literature values although the different residence times and total aerosol loadings make the direct comparison challenging. More aerosol material is expected to evaporate when longer residence times are used. This can be observed when aerosol is heated with varying residence times e.g. in An et al. (2007) and Lee et al. (2010). During the SOAR-1 and MILAGRO campaigns in polluted urban areas in California and Mexico City, volatility of organic aerosol (OA) was investigated at several temperatures up to $230^{\circ} \mathrm{C}$ (Huffman et al., 2009). Slopes of these thermograms are very similar to the slope of our volatil- ity thermogram. The studies by Birmili et al. (2010), Ehn et al. (2007) and Wehner et al. (2005) used similar VDMPS systems with $<2 \mathrm{~s}$ residence time as the one used in this study to investigate the volatility of atmospheric aerosol size distributions around $280-300^{\circ} \mathrm{C}$. Our results fall in between these studies, indicating slightly a higher volatility than the urban study by Birmili et al. (2010), but lower than those of Ehn et al. (2007) and Wehner et al. (2007). It should be borne in mind though that Ehn et al. (2007) and Wehner et al. (2007) both concentrated on the volatility of the nucleation mode instead of the total aerosol mass.

During recent years, a number of studies have pointed out challenges in quantitative interpretation of TD or VDMPS data (Cappa et al., 2010; Riipinen et al., 2010; Saleh et al., 2011; Pierce et al., 2011) for compounds - in particular 


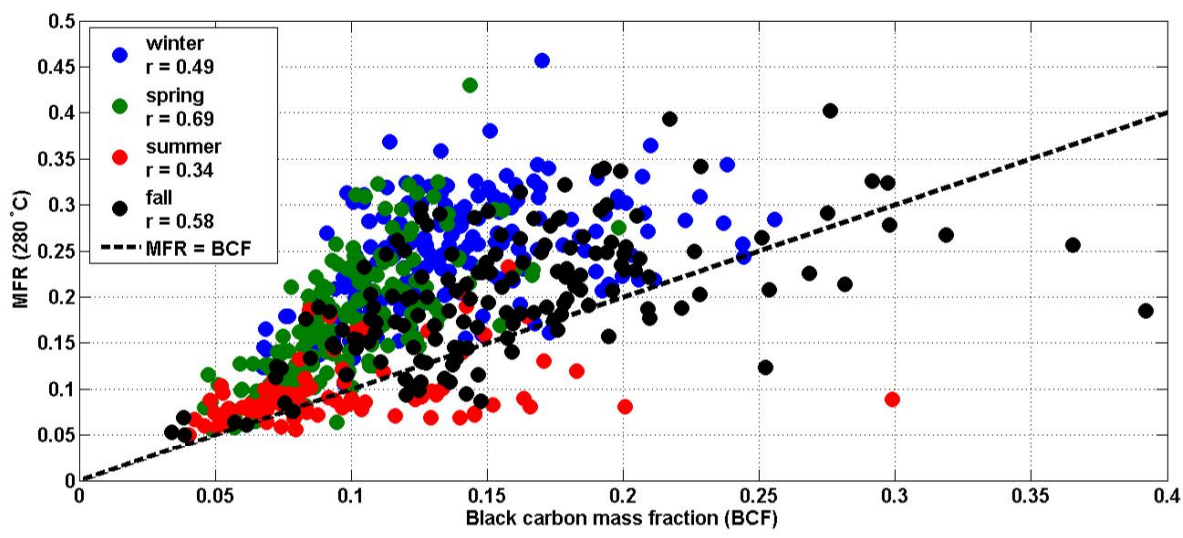

Fig. 7. Mass fraction remaining (MFR) at $280^{\circ} \mathrm{C}$ as a function of $\mathrm{BC}$ mass fraction during different seasons. A clear correlation is observed during winter, spring and fall months ( $\mathrm{p}$-value $<10^{-5}$ ). The black line describes the situation where the entire non-volatile aerosol mass (at $280^{\circ} \mathrm{C}$ in $1.2 \mathrm{~s}$ ) may be due to $\mathrm{BC}$. The existence of measurement points below this line most likely arise from the attribution of all $\mathrm{PM}_{2.5}$ BC to sub-500 $\mathrm{nm}$ aerosol.

mixtures - whose properties are not well-known. Taking into account these uncertainties in the analysis of the VDMPS data, we do not intend to give a quantitative answer on the variation of the thermodynamic properties of the aerosol in Hyytiälä based on the calculated MFR values. However, even accounting for the uncertainties it can be concluded that the material that does not evaporate at temperatures higher than $280^{\circ} \mathrm{C}$ has likely a very low saturation vapor pressure. As an example, using the approach presented by $\mathrm{Ri}$ ipinen et al. (2010), a two-component system consisting of a non-volatile fraction (BC) and a semi-volatile organic fraction (accommodation coefficients of unity, particle diameter $100 \mathrm{~nm}$ and mass concentration of $3.0 \mu \mathrm{g} \mathrm{m}^{-3}$ ) would require an organic vaporization enthalpy of $64 \mathrm{~kJ} \mathrm{~mol}^{-1}$ and saturation vapor pressure of $10^{-6} \mathrm{~Pa}$ (saturation concentration of $0.15 \mu \mathrm{g} \mathrm{m}^{-3}$ or $6 \times 10^{8} \mathrm{~cm}^{-3}$ assuming vapor molecule mass $150 \mathrm{amu}$ ) or lower to reproduce the temperature-dependence of the VDMPS data (see Fig. 6) and to not fully evaporate at $280^{\circ} \mathrm{C}$ over the time of a second (see also Pierce et al., 2011). The obtained vaporization enthalpy value is too low to represent a realistic single-component organic aerosol. However, previous studies have shown that multicomponent organic aerosols (such as probably present in our study) often show a much shallower temperature-dependence than can be represented with a single-component vaporization enthalpy and saturation vapor pressure (e.g. Riipinen et al., 2010). It is also possible that particles react in the heated tube and form compounds with lower volatilities. In any case, the observed non-volatile residual at $280^{\circ} \mathrm{C}$ gives indirect information on the chemical composition of the very low-volatile material in aerosol particles.

\subsection{Contribution of $\mathrm{BC}$ to MFR}

Although located in a rural remote area, polluted air masses transport BC to Hyytiälä. Seasonal behavior of the maxi- mum $\mathrm{BC}$ fraction in aerosol particles (see Eq. 4) is presented in Fig. 5. The BCF was the highest during winter and fall, around $13-15 \%$. In summer and spring months around 8 $10 \%$ of the total aerosol mass consisted of BC.

The positive correlation observed between the $\mathrm{BCF}$ and MFR at $280^{\circ} \mathrm{C}$ (Fig. 7) supports the assumption that BC is connected to the least-volatile fraction of atmospheric aerosol. A similar observation was made by Birmili et al. (2010) in an urban environment. Even though the BCF was the highest during winter and fall (see also Hienola et al., 2012), the best correlation (Pearson correlation) between the BCF and the MFR at $280^{\circ} \mathrm{C}$ was observed during spring $\left(r=0.69, \mathrm{p}\right.$-value $\left.<10^{-5}\right)$. However, during winter and fall also the MFR at $280^{\circ} \mathrm{C}$ was the highest, which may have affected the observed correlations. In general the correlation in summer was the lowest $\left(r=0.34, \mathrm{p}\right.$-value $\left.10^{-3}\right)$, although specifically in summer the $\mathrm{BC}$ concentrations were often of similar magnitude than the concentrations of the material that remained non-volatile at $280^{\circ} \mathrm{C}$. This suggests that in the summer a relatively larger fraction of the $\mathrm{BC}$ is in particles larger than $500 \mathrm{~nm}$ in diameter as compared with the cold months. This is reasonable, since in the winter there are more local sources of $\mathrm{BC}$ producing relatively smaller particles than in the summer when most of the $\mathrm{BC}$ is likely due to longrange transport. Depending on season BC explained 55-87\% (median values) of the non-volatile residual. The lowest contribution of $\mathrm{BC}$ was observed during winter and the highest during summer. In most cases the non-volatile aerosol mass at $280^{\circ} \mathrm{C}$ could not be explained by BC only. A similar finding was reported by Backman et al. (2010) who investigated the behavior of particle single-scattering albedo after heating in an urban background area in Helsinki, Finland. They concluded that $\mathrm{BC}$ alone could not explain the concentrations of material remaining non-volatile at $280^{\circ} \mathrm{C}$. Neither crustal material nor sea salt is a significant contributor to 


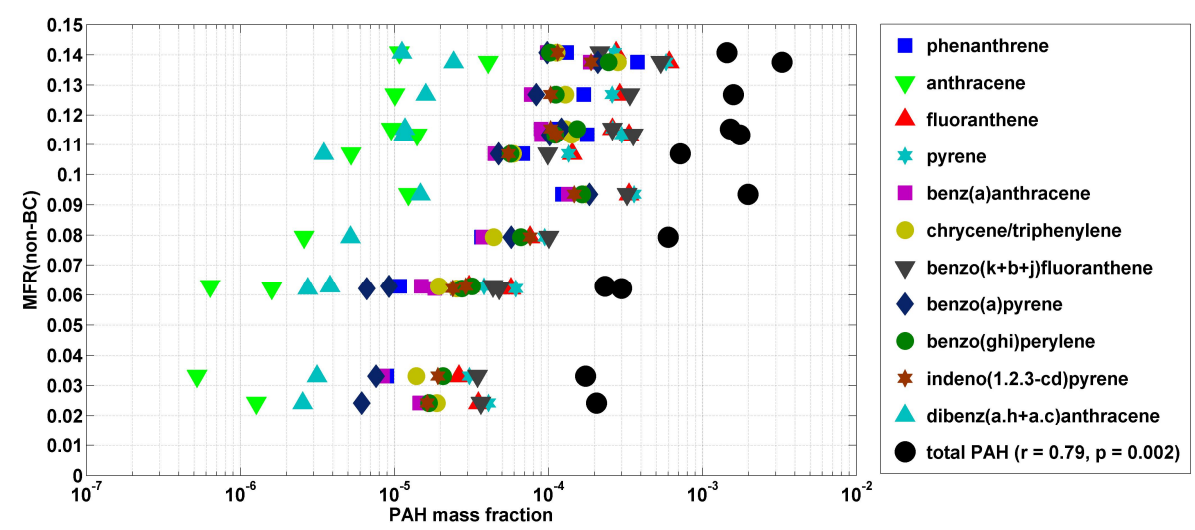

Fig. 8. Aerosol mass fraction remaining $\left(\mathrm{MFR}_{\text {non-BC }}\right)$ at $280^{\circ} \mathrm{C}$ as a function maximum mass fractions of PAHs. Monthly means have been used. Note the logarithmic scale.

submicron aerosol composition in Hyytiälä area (Saarikoski et al., 2005). To get additional information on the chemical composition of the least-volatile aerosol fraction, $\mathrm{MFR}_{\text {non-BC }}$ at $280^{\circ} \mathrm{C}$ was correlated with atmospheric parameters as well as with aerosol chemical composition data obtained from filter analysis and from the AMS.

\subsection{Dependence of MFR $_{\text {non-BC }}$ on environmental variables and PAHs}

Over the whole measurement period the $\mathrm{MFR}_{\text {non-BC }}$ at $280^{\circ} \mathrm{C}$ was higher at lower ambient temperatures $(r=-0.46$ with p-value of $<10^{-5}$ ). Solar radiation did not affect the $\mathrm{MFR}_{\text {non-BC }}$ at $280^{\circ} \mathrm{C}$ as strongly as the ambient temperature $\left(r=-0.27\right.$ with $\mathrm{p}$-value of $\left.<10^{-5}\right)$. This also indicates that the effect of the height of the boundary layer is not as significant as the ambient temperature. In cold conditions the ambient aerosol mixture is different compared to warm air masses due to different vapor and particle sources. The need for e.g. residential heating during winter is high which indicates that there are more very low-volatile anthropogenic compounds in the atmosphere. The SMEAR II sampling lines are at room temperature and aerosol spends more than $5 \mathrm{~s}$ in these lines before arriving at the TD. This should be sufficient for the sample to reach room temperature before being heated to the TD temperature. In addition, the temperature of the aerosol flow inside the TD was measured at the centerline. This suggests that the dependence of the $\mathrm{MFR}_{\text {non- }} \mathrm{BC}$ at $280^{\circ} \mathrm{C}$ on the ambient temperature is not likely to be due to e.g. residence time related artifacts in the aerosol sampling.

The correlation between atmospheric polycyclic aromatic hydrocarbons (PAHs), emitted from combustion processes (Anttila et al., 2005; Rissanen et al., 2006), and the $\mathrm{MFR}_{\text {non-BC }}$ at $280^{\circ} \mathrm{C}$ was investigated. The monthly median values of $\mathrm{MFR}_{\text {non-BC }}$ at $280^{\circ} \mathrm{C}$ in sub- $500 \mathrm{~nm}$ particles as a function of the maximum mass fraction of PAHs are presented in Fig. 8. It can be clearly seen that the particles were relatively more non-volatile with high PAH mass frac- tions. The correlation coefficient between the $\mathrm{MFR}_{\text {non- }} \mathrm{BC}$ at $280^{\circ} \mathrm{C}$ and the sum of PAH-fractions was as high as 0.79 with a p-value of 0.002 (Fig. 8). The mass concentrations of PAHs are so low that their contribution, if there is some, to the $\mathrm{MFR}_{\text {non-BC }}$ at $280^{\circ} \mathrm{C}$ is minuscule. However, the results indicate that aerosol volatility is connected to anthropogenic influence over the whole measurement period. It was also observed that the BCF correlated positively with the PAH mass fraction with a correlation coefficient of 0.64 and a p-value of 0.03 . This result suggests that motor vehicle emissions or other anthropogenic emissions, e.g. from residential heating, are the main source of $\mathrm{BC}$ in Hyytiälä area.

\subsection{Indications of the chemical composition of MFR $_{\text {non-BC }}$}

AMS data were available for two month-long campaigns: one in May-June and one in September-October 2008 (Fig. 1). The aerosol chemical composition as determined from the AMS is presented in Fig. 9 (upper panel). The $\mathrm{MFR}_{\text {non-BC }}$ at $280^{\circ} \mathrm{C}$ was compared to these data (Fig. 9, lower panel). It was assumed that the $\mathrm{MFR}_{\mathrm{non}-\mathrm{BC}}$ at $280^{\circ} \mathrm{C}$ is comparable with the AMS compounds evaporating at $600^{\circ} \mathrm{C}$. During the spring campaign the $\mathrm{MFR}_{\text {non- }} \mathrm{BC}$ at $280^{\circ} \mathrm{C}$ did not have a significant correlation with the mass fractions of any of the AMS-compounds (Fig. 9, lower panel). AMS measurements during fall gave more insight to the chemical composition of the non-volatile (at $280^{\circ} \mathrm{C}$ ) residual. Although the median $\mathrm{MFR}_{\text {non-BC }}$ at $280^{\circ} \mathrm{C}$ was small (Fig. 5), the maximum value for the $\mathrm{MFR}_{\text {non-BC }}$ at $280^{\circ} \mathrm{C}$ was as high as 0.25 . In the following we will concentrate on the comparisons between the VDMPS data and the AMS data from the fall campaign.

The VDMPS was temperature-scanning during the AMS campaigns. This made it possible to study the correlation between the aerosol chemical composition and the $\mathrm{MFR}_{\text {non-BC }}$ at six different temperatures (see Fig. 10 for results from the fall campaign). Ammonia and sulfates correlated positively with the $\mathrm{MFR}_{\text {non-BC }}$ at $280^{\circ} \mathrm{C}$ only at temperatures below 


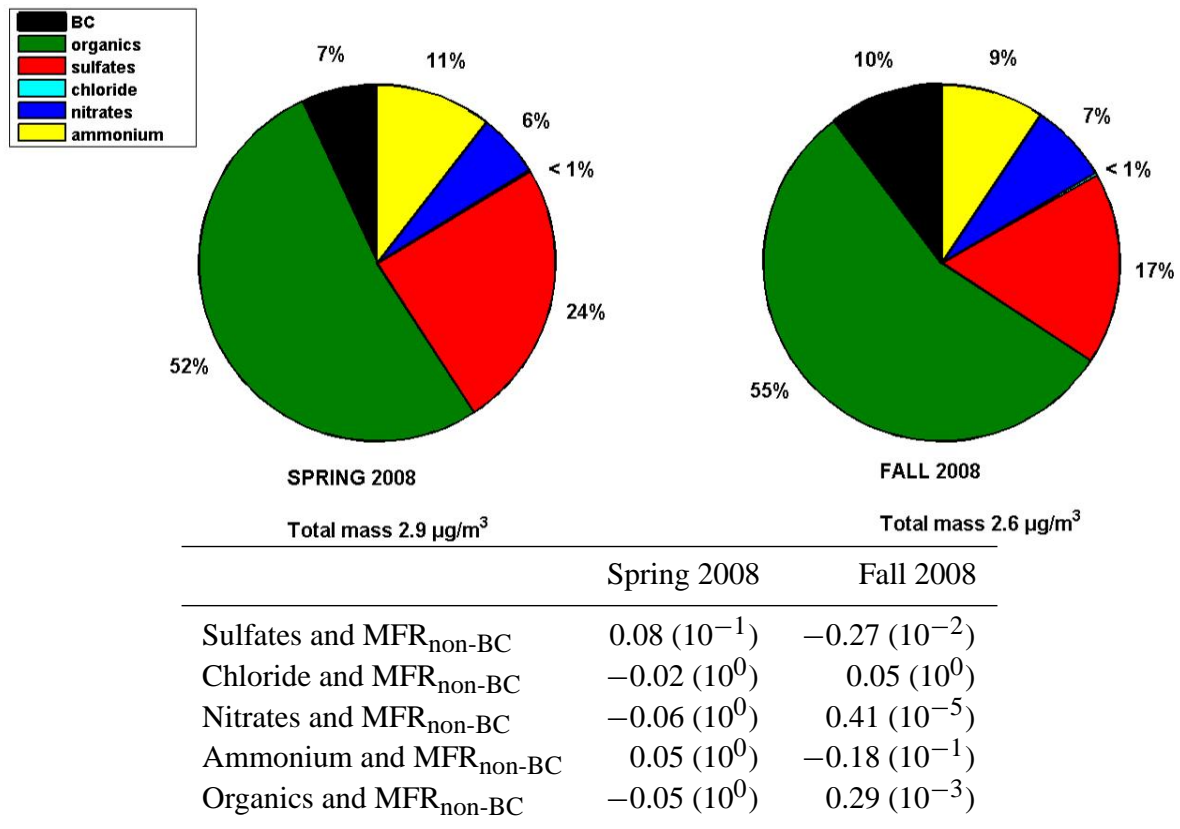

Fig. 9. Median aerosol chemical composition during AMS measurement campaigns in spring and fall 2008 is illustrated in the upper panel. BC mass measured with an aethalometer is included in the total aerosol mass and the median total mass concentrations of particles are provided. The correlation ( $r$ and p-value in parenthesis) between $\mathrm{MFR}_{\text {non-BC }}$ at $280^{\circ} \mathrm{C}$ and mass fractions of AMS-compounds is presented in the lower panel.

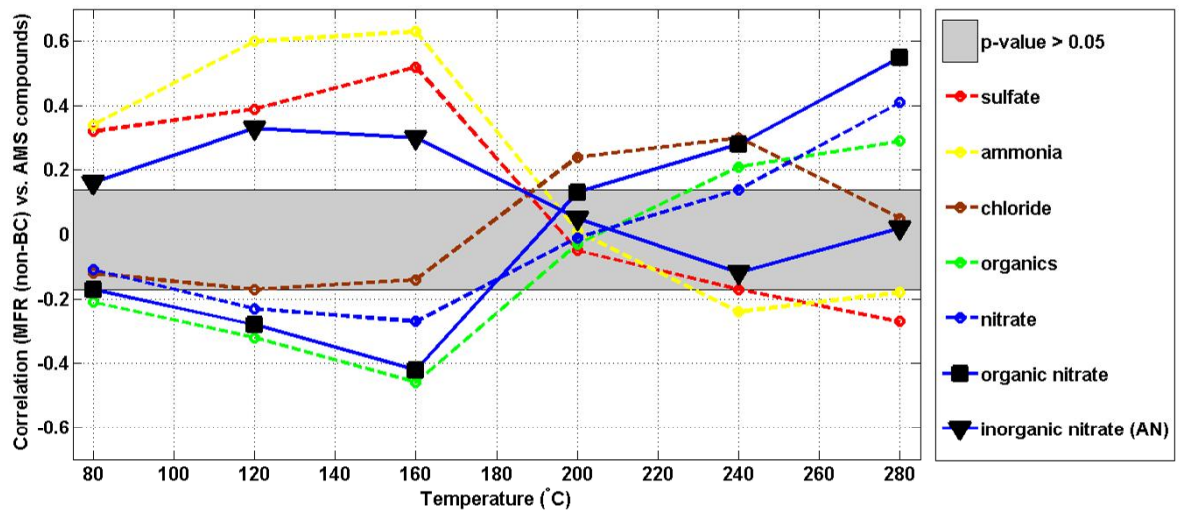

Fig. 10. Correlation coefficients between $\mathrm{MFR}_{\text {non-BC }}$ at $280^{\circ} \mathrm{C}$ and mass fractions of AMS-compounds at six different temperatures. Mass concentrations (/fractions) of ammonium nitrate (AN) and organic nitrate were estimated from the AMS data. The grey area presents the correlation range $(r=-0.17 \ldots 0.14)$ where the correlations start to approach an area of not being statistically significant (p-value $>0.05)$.

$160^{\circ} \mathrm{C}$. This is in line with previous studies reporting evaporation of ammonium sulfate at approximately $200^{\circ} \mathrm{C}$. Nitrates and organics, however, had a statistically significant positive linear correlation with the $\mathrm{MFR}_{\text {non-BC }}$ at $280^{\circ} \mathrm{C}$. Also, a positive correlation between $\mathrm{MFR}_{\text {non-BC }}$ and AMS chloride was observed at high heating temperatures. However, the mass loadings of chloride observed by the AMS suggest the amount of chloride compounds is almost negligible in Hyytiälä (see Fig. 9 upper panel), and the amounts observed are most likely insufficient to have any effect on the $\mathrm{MFR}_{\text {non-BC }}$ within the measurement inaccuracies. During the spring campaign the ammonium-sulfate behavior was similar to the fall campaign, whereas with organics and nitrates no clear correlation was found.

The relative importance of inorganic vs. organic nitrate was estimated by dividing the available ammonium to sulfate and the residual ammonium to nitrate. The remaining nitrate was assumed to be organic. All the nitrate was not bound to ammonium and thus, a notable amount of organic nitrate was also present (see Fig. A1). The correlations between the $\mathrm{MFR}_{\text {non-BC }}$ at $280^{\circ} \mathrm{C}$ and the mass fractions of ammonium nitrate and organic nitrate are illustrated in Fig. 10. It can be 
observed that the $\mathrm{MFR}_{\mathrm{non}-\mathrm{BC}}$ at $280^{\circ} \mathrm{C}$ correlated positively with the mass fraction of organic nitrate at high heating temperatures whereas the correlation behavior of ammonium nitrate was similar to ammonium and sulfate. While the correlations between the AMS mass fractions and the $\mathrm{MFR}_{\text {non- }} \mathrm{BC}$ at $280{ }^{\circ} \mathrm{C}$ were clear, it should be borne in mind that our analysis has been restricted to the total aerosol mass (20$500 \mathrm{~nm}$ ), as no size-dependent AMS data was available. It is therefore not possible to say how the composition of the very low-volatile material is likely to depend on particle size or whether its composition is rather uniform throughout the size distribution.

In the fall 2008 particles arriving at Hyytiälä from the clean sector (i.e. from the forest, Tunved et al., 2006) had relatively more organic nitrates and very low-volatile material in them (Fig. A2, lower panel) as compared with other air mass directions. During spring such a correlation was not observed (Fig. A2, upper panel). Our results therefore suggest that the $\mathrm{MFR}_{\text {non- } \mathrm{BC}}$ at $280^{\circ} \mathrm{C}$ is connected to organic nitrates in the fall period with clean air masses. This conclusion is, however, speculative and additional studies are needed to verify the presence of very low-volatile organonitrates.

Raatikainen et al. (2010) observed that aerosol nitrates, sulfates and ammonium correlated notably with low-volatile oxidized organic aerosol (LV-OOA) during spring 2005. LVOOA was characterized as highly aged organic aerosol with an anthropogenic origin. It is possible that some of these LVOOA compounds may not evaporate at $280^{\circ} \mathrm{C}$ due to e.g. organic polymerization (Kalberer et al., 2004) or salt formation (Smith et al., 2010). However, the existence of very lowvolatile LV-OOA was not clearly indicated by their results. It should be noted, however, that Raatikainen et al. (2010) investigated aerosol volatility in Hyytiälä over a shorter time period and with different instruments than in this study.

Our results, together with the findings of Raatikainen et al. (2010) clearly indicate that the processes controlling the composition of the remaining material in Hyytiälä vary depending on the season and probably no single explanation for the non-volatile residual at $280^{\circ} \mathrm{C}$ can be found.

\section{Summary and conclusions}

Evaporation of 20-500 nm aerosol particles was investigated in a boreal forest site in Hyytiälä at the SMEAR II station during a two and a half year period from January 2008 to May 2010. The long-term measurements of aerosol volatility as well as additional data from the SMEAR II station made it possible to examine the seasonal behavior of the aerosol when heated, as well as to compare the data set with atmospheric parameters and with direct aerosol composition measurements. The higher the heating temperature was the more aerosol material evaporated, the temperature response of the evaporation being similar as in previous studies. At $80^{\circ} \mathrm{C}$
$86 \%$ of total aerosol mass remained after heating, whereas the mass fraction remaining (MFR) was $19 \%$ at $280^{\circ} \mathrm{C}$.

It was found that the MFR varied with season. During winter months the MFR was the highest at all heating temperatures. In order to explain the existence of the MFR even at temperatures as high as $280^{\circ} \mathrm{C}$ as well as its seasonal behavior, additional measurements, such as $\mathrm{BC}$ data, were included in the analysis. The maximum possible fraction of MFR at $280^{\circ} \mathrm{C}$ explained by $\mathrm{BC}$ was dependent on the season: it was $55 \%$ in the winter (median over December-February), $57 \%$ in the spring (median over March-May), $87 \%$ in the summer (median over June-August) and $75 \%$ in the fall (median over September-November). Even though the aerosol BC fraction (BCF) was the highest during winter and fall months, during summer on some days all the non-volatile mass (at $280^{\circ} \mathrm{C}$ ) could have, in principle, been explained by BC. However, the correlation between the BCF and the MFR at $280^{\circ} \mathrm{C}$ was the poorest during summer months - this could be partly due to small amount of data from summer months, but also probably linked to the contribution of other factors in defining the volatility of the aerosol in the summer as well.

Crustal material and sea salt are minor contributors to the total submicron aerosol mass in Hyytiälä, and the observed $\mathrm{BC}$ alone could not explain the existence of the material that did not volatilize even at $280^{\circ} \mathrm{C}$. Thus, roughly half of the aerosol non-volatile mass is explained by other compounds than BC, sea salt or crustal material. The properties of these non-BC compounds (forming the $\mathrm{MFR}_{\text {non-BC }}$ at $280^{\circ} \mathrm{C}$ ) were investigated further by correlating the $\mathrm{MFR}_{\text {non- } \mathrm{BC}}$ at $280^{\circ} \mathrm{C}$ with meteorological data and aerosol mass spectrometer data from spring and fall 2008. However, no single factor explaining the $\mathrm{MFR}_{\text {non-BC }}$ at $280^{\circ} \mathrm{C}$ was found.

Ambient temperature had a marked negative correlation with the $\mathrm{MFR}_{\text {non-BC }}$ at $280^{\circ} \mathrm{C}$. It was also observed that high PAH aerosol mass fractions corresponded to high values of the $\mathrm{MFR}_{\text {non- } \mathrm{BC}}$ at $280^{\circ} \mathrm{C}$. These results suggest that the nonvolatile aerosol fraction at $280^{\circ} \mathrm{C}$ may contain also other compounds from anthropogenic sources in addition to $\mathrm{BC}$. Positive correlations between the estimated organic nitrate and organic aerosol mass fractions from the AMS and the $\mathrm{MFR}_{\text {non-BC }}$ at $280^{\circ} \mathrm{C}$ were observed in fall 2008 . These results suggest that very low-volatile organic compounds, e.g. polymerized organics or organonitrates, might exist in the least-volatile fraction of atmospheric aerosols not evaporating at $280^{\circ} \mathrm{C}$.

Our results indicate aerosol evaporation at $280^{\circ} \mathrm{C}$ (with a residence time of $1.2 \mathrm{~s}$ ) in a boreal forest environment cannot be explained with any single parameter - but rather is dependent on several environmental factors, varies with season and is affected by both anthropogenic and biogenic factors. 


\section{Appendix A}

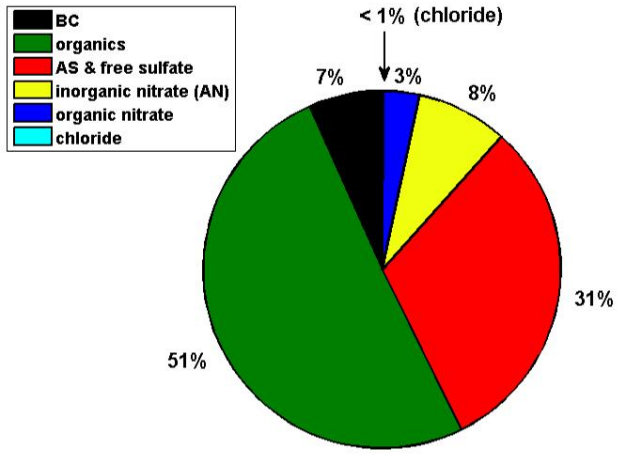

SPRING 2008

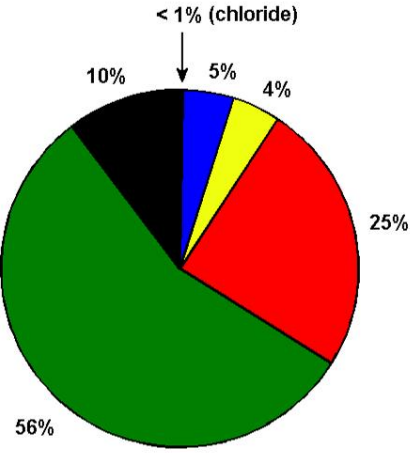

FALL 2008

Fig. A1. Median aerosol chemical composition during AMS measurement campaigns in spring and fall 2008. Ammonium has been divided to sulfate and nitrate to form ammonium sulfate (AS) and ammonium nitrate (AN). Nitrate that is not neutralized by ammonium is assumed to be organic nitrate.

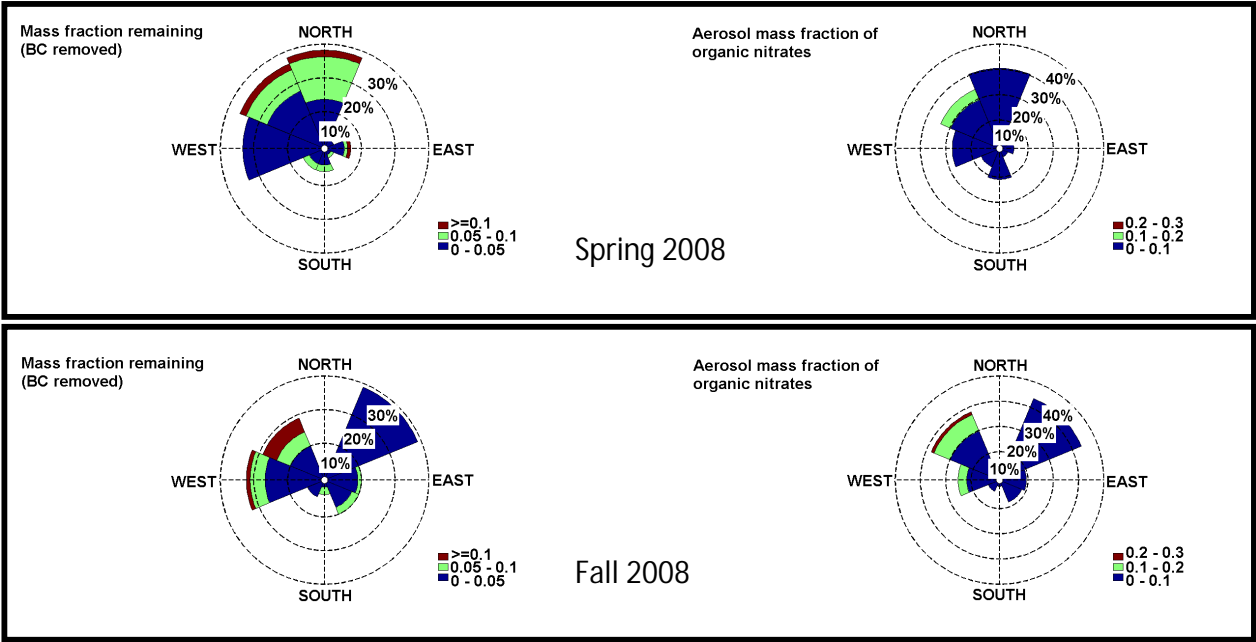

Fig. A2. Wind roses of aerosol mass fraction remaining (MFR ${ }_{\text {non-BC }}$ ) after heating to $280^{\circ} \mathrm{C}$ and the mass fraction of organic nitrates during AMS measurement campaign in spring 2008 (upper panel) and in fall 2008 (lower panel). The colors represent the mass fractions, and the percent values correspond to the amount of data from each wind direction bin. In fall 2008 aerosol organic nitrate mass fraction and $\mathrm{MFR}_{\text {non-BC }}$ at $280^{\circ} \mathrm{C}$ were correlating.

Table A1. Absorption mass cross-sections, $\sigma_{\mathrm{abs}, 0}$ (from the manufacturer) and $\sigma_{\mathrm{abs}}$ (calculated based on Petzold and Schönlinner, 2004), and $C$ parameters for correcting the BC concentrations measured with an aethalometer. $C$ factors given are determined from Hohenpeissenberg data (Collaud-Coen et al., 2010) but because of the similar forest environment, these factors were assumed to describe the Hyytiälä aerosol alike.

\begin{tabular}{lrrr}
\hline $\begin{array}{l}\text { Wavelength } \lambda \\
(\mathrm{nm})\end{array}$ & $\begin{array}{r}\sigma_{\mathrm{abs}, 0} \\
\left(\mathrm{~m}^{2} \mathrm{~g}^{-1}\right)\end{array}$ & $\begin{array}{r}\sigma_{\text {abs }} \\
\left(\mathrm{m}^{2} \mathrm{~g}^{-1}\right)\end{array}$ & $C$ \\
\hline 370 & 39.53 & 11.36 & 2.64 \\
470 & 31.12 & 8.95 & 2.75 \\
521 & 28.07 & 8.07 & 2.81 \\
590 & 24.79 & 7.13 & 2.87 \\
660 & 22.16 & 6.37 & 2.93 \\
880 & 16.62 & 4.78 & 3.09 \\
950 & 15.39 & 4.43 & 3.13 \\
\hline
\end{tabular}


Acknowledgements. This work was financially supported by the University of Helsinki three-year research grant (No. 490082), by Maj and Tor Nessling Foundation (No. 2010143), Academy of Finland (No. 139656), Finnish Center of Excellence grant (No. 141135) and European Research Council grant ATMNUCLE (No. 227463) and ATMOGAIN (No. 278277), which are gratefully acknowledged. The staff of SMEAR II station is acknowledged for their support during the measurements. Pasi Aalto is acknowledged for designing and maintaining the VDMPS instrument and measurements.

Edited by: B. Ervens

\section{References}

Aalto, P., Hämeri, K., Becker, E., Weber, R., Salm, J., Mäkelä, J. M., Hoell, C., O’Dowd, C.D., Karlsson, H.-C., Väkevä, M., Koponen, I. K., Buzorius, G., and Kulmala, M.: Physical characterization of aerosol particles during nucleation events, Tellus B, 53, 344-358, 2001.

An, W. J., Pathak, R. K., Lee, B. H., and Pandis, S. N.: Aerosol Volatility Measurement Using an Improved Thermodenuder: Application to Secondary Organic Aerosol, J. Aerosol Sci., 38, 305314, 2007.

Anderson, T., Covert, D., Marshall, S., Laucks, M., Charlson, R., Waggoner, A., Ogren, J., Caldow, R., Holm, R., Quant, F., Sem, G., Wiedensohler, A., Ahlquist, N., and Bates, T.: Performance characteristics of a high-sensitivity, three-wavelength, total scatter/backscatter nephelometer, J. Atmos. Ocean. Tech., 13, 967985, 1996.

Andreae, M. O. and Gelencsér, A.: Black carbon or brown carbon? The nature of light-absorbing carbonaceous aerosols, Atmos. Chem. Phys., 6, 3131-3148, doi:10.5194/acp-6-3131-2006, 2006.

Anttila, P., Rissanen, T., Shimmo, M., Kallio, M., Hyötyläinen, T., Kulmala, M., and Riekkola, M.-L.: Organic compounds in atmospheric aerosols from a Finnish coniferous forest, Boreal Environ. Res., 10, 371-384, 2005.

Arnott, W. P., Hamasha, K., Moosmüller, H., Sheridan, P. J., and Ogren, J. A.: Towards Aerosol Light-Absorption Measurements with a 7-Wavelength Aethalometer: Evaluation with a Photoacoustic Instrument and 3-Wavelength Nephelometer, Aerosol Sci. Technol., 39, 17-29, 2005.

Backman, J., Virkkula, A., Petäjä, T., Aurela, M., Frey, A., and Hillamo, R.: Impacts of volatilisation on light scattering and filter-based absorption measurements: a case study, Atmos. Meas. Tech., 3, 1205-1216, doi:10.5194/amt-3-1205-2010, 2010.

Barsanti, K. C., McMurry, P. H., and Smith, J. N.: The potential contribution of organic salts to new particle growth, Atmos. Chem. Phys., 9, 2949-2957, doi:10.5194/acp-9-2949-2009, 2009.

Birmili, W., Heinke, K., Pitz, M., Matschullat, J., Wiedensohler, A., Cyrys, J., Wichmann, H.-E., and Peters, A.: Particle number size distributions in urban air before and after volatilisation, Atmos. Chem. Phys., 10, 4643-4660, doi:10.5194/acp-10-46432010, 2010.

Bohren, C. F. and Huffman, D. R.: Absorption and Scattering of Light by Small Particles, John Wiley \& Sons, New York, 1983.
Bond, T. C., Anderson, T. L., and Campbell, D.: Calibration and Intercomparison of Filter-Based Measurements of Visible Light Absorption by Aerosols, Aerosol Sci. Technol., 30, 582-600, 1999.

Burtscher, H., Baltensperger, U., Buckowiecki, N., Cohn, P., Huglin, C., Mohr, M., Matter, U., Nyeki, S., Schmatloch, V., Streit, N., and Weingartner, E.: Separation of volatile and nonvolatile aerosol fractions by thermodesorption: instrumental development and applications, J. Aerosol Sci., 32, 427-442, 2001.

Cabada, J. C., Khlystov, A., Wittig, A. E., Pilinis, C., and Pandis, S. N.: Light scattering by fine particles during the Pittsburgh Air Quality Study: Measurements and modeling, J. Geophys. Res., 109, D16S03, doi:10.1029/2003JD004155, 2004.

Cappa, C. D.: A model of aerosol evaporation kinetics in a thermodenuder, Atmos. Meas. Tech., 3, 579-592, doi:10.5194/amt3-579-2010, 2010.

Cappa, C. D. and Wilson, K. R.: Evolution of organic aerosol mass spectra upon heating: implications for OA phase and partitioning behavior, Atmos. Chem. Phys., 11, 1895-1911, doi:10.5194/acp11-1895-2011, 2011.

Collaud Coen, M., Weingartner, E., Apituley, A., Ceburnis, D., Fierz-Schmidhauser, R., Flentje, H., Henzing, J. S., Jennings, S. G., Moerman, M., Petzold, A., Schmid, O., and Baltensperger, U.: Minimizing light absorption measurement artifacts of the Aethalometer: evaluation of five correction algorithms, Atmos. Meas. Tech., 3, 457-474, doi:10.5194/amt-3-457-2010, 2010.

Dal Maso, M., Kulmala, 5 M., Riipinen, I., Wagner, R., Hussein, T., Aalto, P. P., and Lehtinen, K. E. J.: Formation and growth of fresh atmospheric aerosols: eight years of aerosol size distribution data from SMEAR II, Hyytiälä, Finland, Boreal Environ. Res., 10, 323-336, 2005.

Davidson, C. I., Phalen, R. F., and Solomon, P. A.: Airborne particulate matter and human health: A review, Aerosol Sci. Technol., 39, 737-749, 2005.

Draxler, R. R. and Hess, G. D.: Description of the HYSPLIT_4 modeling system, NOAA Tech. Memo. ERL ARL-224, NOAA Air Resources Laboratory, Silver Spring, MD, 24 pp., 1997.

Draxler, R. R. and Rolph, G. D.: HYSPLIT (HYbrid Single-Particle Lagrangian Integrated Trajectory), Model access via NOAA ARL READY Website (http://ready.arl.noaa.gov/HYSPLIT. php), NOAA Air Resources Laboratory, Silver Spring, MD, 2011.

Drewnick F., Hings S. S., DeCarlo P., Jayne J. T., Gonin M., Fuhrer K., Weimer S., Jimenez J. L., Demerjian K. L., Borrmann S., and Worsnop D. R.: A new time-of-flight aerosol mass spectrometer (TOF-AMS) - Instrument description and first field deployment, Aerosol Sci. Tech., 39, 637-658, 2005.

Ehn, M., Petäjä, T., Birmili, W., Junninen, H., Aalto, P., and Kulmala, M.: Non-volatile residuals of newly formed atmospheric particles in the boreal forest, Atmos. Chem. Phys., 7, 677-684, doi:10.5194/acp-7-677-2007, 2007.

Faulhaber, A. E., Thomas, B. M., Jimenez, J. L., Jayne, J. T., Worsnop, D. R., and Ziemann, P. J.: Characterization of a thermodenuder-particle beam mass spectrometer system for the study of organic aerosol volatility and composition, Atmos. Meas. Tech., 2, 15-31, doi:10.5194/amt-2-15-2009, 2009.

Fuentes, E. and McFiggans, G.: A modeling approach to evaluate the uncertainty in estimating the evaporation behaviour and volatility of organic aerosols, Atmos. Meas. Tech., 5, 735-757, 
doi:10.5194/amt-5-735-2012, 2012.

Goldstein, A. E. and Galbally, I. E.: Known and Unexplored Organic Constituents in the Earth's Atmosphere, Environ. Sci. Technol., 41, 1514-1521, 2007.

Hansen, A. D. A., Rosen, H., and Novakov, T.: The Aethalometer - an Instrument for the Real-Time Measurement of Optical Absorption by Aerosol Particles, Sci. Total Environ., 36, 191-196, 1984.

Hari, P. and Kulmala, M.: Station for Measuring EcosystemAtmosphere Relations (SMEAR II), Boreal Env. Res., 10, 315$322,2005$.

Hienola, A. I., Pietikäinen, J.-P., Jacob, D., Pozdun, R., Petäjä, T., Hyvärinen, A.-P., Kerminen, V.-M., Kulmala, M., and Laaksonen, A.: Black carbon concentration and deposition estimations in Finland by the regional aerosol-climate model REMO-HAM, Atmos. Chem. Phys. Discuss., 12, 24395-24435, doi:10.5194/acpd-12-24395-2012, 2012.

Hitzenberger, R. and Tohno, S.: Comparison of black carbon (BC) aerosols in two urban areas - concentrations and size distributions, Atmos. Environ., 35, 2153-2167, 2001.

Hoppel, W. A.: Determination of the aerosol size distribution from the mobility distribution of the charged fraction of aerosols, J. Aerosol Sci., 9, 41-54, 1978.

Huffman, J. A., Ziemann, P. J., Jayne, J. T., Worsnop, D. R., and Jimenez, J. L.: Development and Characterization of a FastStepping/Scanning Thermodenuder for Chemically-Resolved Aerosol Volatility Measurements, Aerosol Sci. Technol., 42, 395-407, 2008

Huffman, J. A., Docherty, K. S., Aiken, A. C., Cubison, M. J., U1brich, I. M., DeCarlo, P. F., Sueper, D., Jayne, J. T., Worsnop, D. R., Ziemann, P. J., and Jimenez, J. L.: Chemically-resolved aerosol volatility measurements from two megacity field studies, Atmos. Chem. Phys., 9, 7161-7182, doi:10.5194/acp-9-71612009, 2009.

Intergovernmental Panel on Climate Change: Climate Change 2007 - The Physical Science Basis: Contribution of Working Group I to the Fourth Assessment Report of the IPCC, Cambridge University Press, Cambridge, 2007.

Jayne, J. T., Leard, D. C., Zhang, X., Davidovits, P., Smith, K. A., Kolb, C. E., and Worsnop, D. R.: Development of an aerosol mass spectrometer for size and composition analysis of submicron particles, Aerosol Sci. Technol., 33, 49-70, 2000.

Jimenez, J. L., Canagaratna, M. R., Donahue, N. M., Prevot, A. S. H., and Zhang, Q.: Evolution of Organic Aerosols in the Atmosphere, Science, 326, 1525-1529, 2009.

Johnson, G. R., Ristovski, Z., and Morawska, L.: Method for measuring the hygroscopic behaviour of lower volatility fractions in an internally mixed aerosol, J. Aerosol Sci., 35, 443-455, 2004.

Jokinen, V. and Mäkelä, J. M.: Closed-loop arrangement with critical orifice for DMA sheath/excess flow system, J. Aerosol Sci., 28, 643-648, 1997.

Kalberer, M., Paulsen, D., Sax, M., Steinbacher, M., Dommen, J., and Prevot, A.: Identification of Polymers as Major Components of Atmospheric Organic Aerosols, Science, 303, 1659-1662, 2004

Kanakidou, M., Seinfeld, J. H., Pandis, S. N., Barnes, I., Dentener, F. J., Facchini, M. C., Van Dingenen, R., Ervens, B., Nenes, A., Nielsen, C. J., Swietlicki, E., Putaud, J. P., Balkanski, Y., Fuzzi, S., Horth, J., Moortgat, G. K., Winterhalter, R., Myhre, C. E.
L., Tsigaridis, K., Vignati, E., Stephanou, E. G., and Wilson, J.: Organic aerosol and global climate modelling: a review, Atmos. Chem. Phys., 5, 1053-1123, doi:10.5194/acp-5-1053-2005, 2005.

Kannosto, J., Virtanen, A., Lemmetty, M., Mäkelä, J. M., Keskinen, J., Junninen, H., Hussein, T., Aalto, P., and Kulmala, M.: Mode resolved density of atmospheric aerosol particles, Atmos. Chem. Phys., 8, 5327-5337, doi:10.5194/acp-8-5327-2008, 2008.

Kulmala, M., Hämeri, K., Aalto, P. P., Mäkelä, J. M., Pirjola, L., Nilsson, E. D., Buzorius, G., Rannik, Ü., Dal Maso, M., Seidl, W., Hoffmann, T., Janson, R., Hansson, H.-C., Viisanen, Y., Laaksonen, A., and O'Dowd, C. D.: Overview of the international project on biogenic aerosol formation in the boreal forest (BIOFOR), Tellus B, 53, 324-343, 2001.

Kulmala, M., Vehkamaki, H., Petäjä, T., Dal Maso, M., Lauria, A., Kerminen, V.-M., Birmili, W., and McMurry, P. H.: Formation and growth rates of ultrafine atmospheric particles: a review of observations, J. Aerosol Sci., 35, 143-176, 2004.

Lee, B. H., Kostenidou, E., Hildebrandt, L., Riipinen, I., Engelhart, G. J., Mohr, C., DeCarlo, P. F., Mihalopoulos, N., Prevot, A. S. H., Baltensperger, U., and Pandis, S. N.: Measurement of the ambient organic aerosol volatility distribution: application during the Finokalia Aerosol Measurement Experiment (FAME2008), Atmos. Chem. Phys., 10, 12149-12160, doi:10.5194/acp10-12149-2010, 2010.

Liu, P., Deng, R., Smith, K., Williams, L., Jayne, J., Canagaratna, M., Moore, K., Onasch, T., Worsnop, D. R., and Deshler, T. Transmission Efficiency of an Aerodynamic Focusing Lens System: Comparison of Model Calculations and Laboratory Measurements for the Aerodyne Aerosol Mass Spectrometer, Aerosol Sci. Tech., 41, 721-733, 2007.

Lohmann, U. and Feichter, J.: Global indirect aerosol effects: a review, Atmos. Chem. Phys., 5, 715-737, doi:10.5194/acp-5-7152005, 2005.

McMeeking, G. R., Hamburger, T., Liu, D., Flynn, M., Morgan, W. T., Northway, M., Highwood, E. J., Krejci, R., Allan, J. D., Minikin, A., and Coe, H.: Black carbon measurements in the boundary layer over western and northern Europe, Atmos. Chem. Phys., 10, 9393-9414, doi:10.5194/acp-10-9393-2010, 2010.

Mäkelä, J. M., Aalto, P., Jokinen, V., Pohja, T., Nissinen, A., Palmroth, S., Markkanen, T., Seitsonen, K., Lihavainen, H., and Kulmala, M.: Observations of ultrafine aerosol particle formation and growth in boreal forest, Geophys. Res. Lett., 24, 1219-1222, 1997.

Nel, A.: Air Pollution-Related Illness: Effects of Particles, Science, 308, 804-806, 2005.

O’Dowd, C. D., Becker, E., Mäkelä, J. M., and Kulmala, M: Aerosol physico-chemical characteristics over a boreal forest determined by volatility analysis, Boreal Environ. Res., 5, 337-348, 2000.

Petzold, A. and Schönlinner, M.: Multi-angle absorption photometry - a new method for the measurement of aerosol light absorption and atmospheric black carbon, J. Aerosol Sci., 35, 421-441, 2004.

Philippin, S., Wiedensohler, A., and Stratmann, F.: Measurements of non-volatile fractions of pollution aerosols with an eight-tube Volatility Tandem Differential Mobility Analyzer (VTDMA-8), J. Aerosol Sci., 35, 185-203, 2004.

Pierce, J. R., Riipinen, I., Kulmala, M., Ehn, M., Petäjä, T., Junninen, H., Worsnop, D. R., and Donahue, N. M.: Quantification of 
the volatility of secondary organic compounds in ultrafine particles during nucleation events, Atmos. Chem. Phys., 11, 9019 9036, doi:10.5194/acp-11-9019-2011, 2011.

Raatikainen, T., Vaattovaara, P., Tiitta, P., Miettinen, P., Rautiainen, J., Ehn, M., Kulmala, M., Laaksonen, A., and Worsnop, D. R.: Physicochemical properties and origin of organic groups detected in boreal forest using an aerosol mass spectrometer, Atmos. Chem. Phys., 10, 2063-2077, doi:10.5194/acp-10-20632010, 2010.

Ramanathan, V., Crutzen, P. J., Kiehl, J. T., and Rosenfeld, D.: Aerosol, climate, and the hydrological cycle, Science, 294, 2119-2124, 2001.

Reid, J. S., Hobbs, P. V., Liousse, C., Vanderlei Martins, J., Weiss, R. E., and Eck, T. F.: Comparisons of Techniques for Measuring Shortwave Absorption and Black Carbon Content of Aerosols from Biomass Burning in Brazil, J. Geophys. Res., 103, 3203132040, 1998.

Riipinen, I., Pierce, J. R., Donahue, N. M., and Pandis, S. N.: Equilibration time scales of organic aerosol inside thermodenuders: Evaporation kinetics versus thermodynamics, Atmos. Environ., 44, 597-607, 2010.

Rissanen, T., Hyötyläinen, T., Kallio, M., Kulmala, M., and Riekkola, M.: Characterization of organic compounds in aerosol particles from coniferous forest by GC-MS, Chemosphere, 64, 1185-1195, 2006.

Robinson, A. L., Donahue, N. M., Shrivastava, M. K., Weitkamp, E. A., Sage, A. M., Grieshop, A. P., Lane, T. E., Pierce, J. R., and Pandis, S. N.: Rethinking organic aerosols: semivolatile emissions and photochemical aging, Science, 315, 1259-1262, 2007.

Rosenfeld, D., Lohmann, U., Raga, G. B., O’Dowd, C. D., Kulmala, M., Fuzzi, S., Reissell, A., and Andreae, M. O.: Flood or drought: How do aerosols affect precipitation?, Science, 321, 1309-1313, 2008.

Saarikoski, S., Mäkelä, T., Hillamo, R., Aalto, P. P., Kerminen, V.-M., and Kulmala, M.: Physico-chemical characterization and mass closure of size-segregated atmospheric aerosols in Hyytiälä, Finland, Boreal Env. Res., 10, 385-400, 2005.

Saleh, R., Shihadeh, A., and Khlystov, A.: On transport phenomena and equilibration time scales in thermodenuders, Atmos. Meas. Tech., 4, 571-581, doi:10.5194/amt-4-571-2011, 2011.

Smith, J., Barsanti, K., Friedli, H., Ehn, M., Kulmala, M., Collins, D., Scheckman, J., Williams, B., and McMurry, P.: Observations of aminium salts in atmospheric nanoparticles and possible climatic implications, P. Natl. Acad. Sci., 107, 6634-6639, doi:10.1073/pnas.0912127107, 2010.

Spracklen, D., Carslaw, K., Kulmala, M., Kerminen, V.-M., Sihto, S.-L., Riipinen, I., Merikanto, J., Mann, G., Chipperfield, M., Wiedensohler, A., Birmili, W., and Lihavainen, H.: Contribution of particle formation to global cloud condensation nuclei concentrations, Geophys. Res. Lett., 35, L06808, doi:10.1029/2007GL033038, 2008.

Stolzenburg, M. R. and McMurry, P. H.: An ultrafine aerosol condensation nucleus counter, Aerosol Sci. Technol., 14, 48-65, 1991.

Tiitta, P., Miettinen, P., Vaattovaara, P., Joutsensaari, J., Petäjä, T., Virtanen, A., Raatikainen, T., Aalto, P., Portin, H., Romakkaniemi, S., Kokkola, H., Lehtinen, K. E. J., Kulmala, M., and Laaksonen, A.: Roadside aerosol study using hygroscopic, organic and volatility TDMAs: Characterization and mixing state, Atmos. Environ., 44, 976-986, 2010.

Tunved, P., Hansson, H. C., Kerminen, V. M., Strom, J., Dal Maso, M., Lihavainen, H., Viisanen, Y., Aalto, P. P., Komppula, M., and Kulmala, M.: High natural aerosol loading over boreal forests, Science, 312, 261-263, 2006.

Turpin, B., Saxena, P., and Andrews, E.: Measuring and simulating particulate organics, Atmos. Environ., 34, 2983-3013, 2000.

Vesala, T., Haataja, J., Aalto, P., Altimir, N., Buzorius, G., Garam, E., Hämeri, K., Ilvesniemi, H., Jokinen, V., Keronen, P., Lahti, T., Markkanen, T., Mäkelä, J., Nikinmaa, E., Palmroth, S., Palva, L., Pohja, T., Pumpanen, J., Rannik, U., Siivola, E., Ylitalo, H., Hari, P., and Kulmala, M.: Long-term field measurements of atmosphere-surface interactions in boreal forest combining forest ecology, micrometeorology, aerosol physics and atmospheric chemistry, Trends Heat, Mass Mom. Trans., 4, 17-35, 1998.

Vestenius, M., Leppänen, S., Anttila, P., Kyllönen, K., Hatakka, J., Hellen, H., Hyvärinen, A.-P., and Hakola, H.: Background concentrations and source apportionment of polycyclic aromatic hydrocarbons in South-Eastern Finland, Atmos. Environ., 45, 3391-3399, 2011.

Villani, P., Picard, D., Marchand, N., and Laj, P.: Design and Validation of a Volatility Tandem Differential Mobility Analyzer (VTDMA), Aerosol Sci. Technol., 41, 898-906, 2007.

Virkkula, A., Mäkelä, T., Hillamo, R., Yli-Tuomi, T., Hirsikko, A., Hämeri, K., and Koponen, I. K.: A simple procedure for correcting loading effects of aethalometer data, J. Air Waste Manage. Assoc., 57, 1214-1222, 2007.

Wehner, B., Philippin, S., and Wiedensohler, A.: Design and calibration of a thermodenuder with an improved heating unit to measure the size-dependent volatile fraction of aerosol particles, J. Aerosol Sci., 33, 1087-1093, 2002.

Wehner, B., Philippin, S., Wiedensohler, A., Scheer, V., and Vogt, R.: Variability of non-volatile fractions of atmospheric aerosol particles with traffic influence, Atmos. Environ., 38, 6081-6090, 2004.

Wehner B., Petäjä, T., Boy, M., Engler, C., Birmili, W., Tuch, T., Wiedensohler, A., and Kulmala, M.: The contribution of sulfuric acid and non-volatile compounds on the growth of freshly formed atmospheric aerosols, Geophys. Res. Lett., 32, L17810, doi:10.1029/2005GL023827, 2005.

Weingartner, E., Saathof, H., Schnaiter, M., Streit, N., Bitnar, B., and Baltensperger, U.: Absorption of light by soot particles: Determination of the absorption coefficient by means of aethalometers, J. Aerosol Sci., 13, 1445-1463, 2003.

Zhang, Q., Jimenez, J. L., Canagaratna, M. R., Allan, J. D., Coe, H., Ulbrich, I., Alfarra, M. R., Takami, A., Middlebrook, A. M., Sun, Y. L., Dzepina, K., Dunlea, E., Docherty, K., DeCarlo, P. F., Salcedo, D., Onasch, T., Jayne, J. T., Miyoshi, T., Shimono, A., Hatakeyama, S., Takegawa, N., Kondo, Y., Schneider, J., Drewnick, F., Weimer, S., Demerjian, K., Williams, P., Bower, K., Bahreini, R., Cotrell, L., Griffin, R. J., Rautiainen, J., Sun, J. Y., Zhang, Y. M., and Worsnop, D. R.: Ubiquity and dominance of oxygenated species in organic aerosols in anthropogenicallyinfluenced Northern Hemisphere mid-latitudes, Geophys. Res. Lett., 34, L13801, doi:10.1029/2007GL029979, 2007. 